Original article

\title{
Novel 1,4-benzoxazine and 1,4-benzodioxine inhibitors of angiogenesis
}

\author{
Miloš Ilić ${ }^{a}$, Janez Ilaša ${ }^{a}$, Petra Dunkel ${ }^{b}$, Péter Mátyus ${ }^{b}$, Andrej Boháčc ${ }^{c}$, Sandra Liekens ${ }^{d, *}$, Danijel Kikelj a,** \\ ${ }^{a}$ University of Ljubljana, Faculty of Pharmacy, Aškerčeva 7, SI - 1000 Ljubljana, Slovenia \\ ${ }^{\mathrm{b}}$ Semmelweis University, Department of Organic Chemistry, Högyes E. u. 7, 1092 Budapest, Hungary \\ c Comenius University, Faculty of Natural Sciences, Department of Organic Chemistry, Mlynská dolina, 84215 Bratislava, Slovakia \\ ${ }^{\mathrm{d}}$ Rega Institute for Medical Research, Minderbroedersstraat 10, B-3000 Leuven, Belgium
}

\section{A R T I C L E I N F O}

\section{Article history:}

Received 13 April 2012

Received in revised form

24 September 2012

Accepted 1 October 2012

Available online 8 October 2012

\section{Keywords:}

Angiogenesis

Thrombin

GPIIb/IIIa antagonist

Vascular endothelial growth factor

\begin{abstract}
A B S T R A C T
Esters of 1,4-benzoxazine and 1,4-benzodioxine compounds $\mathbf{1}$ and 10, which combine thrombin inhibitory and GPIIb/IIIa antagonistic activity in one molecule are shown to inhibit endothelial cell migration and tube formation in vitro and angiogenesis in the chicken chorioallantoic membrane (CAM) assay. The corresponding carboxylic acids $\mathbf{1}\left(\mathrm{R}^{2}=\mathrm{H}\right)$ and $\mathbf{1 1}$ were devoid of anti-angiogenic activity, most probably due to their insufficient entry into the cell. Although thrombin inhibition remains the most probable explanation for their inhibition of angiogenesis, VEGFR2 kinase assay suggest that other targets such as VEGFR2 might be involved.
\end{abstract}

(c) 2012 Elsevier Masson SAS. All rights reserved.

\section{Introduction}

The association of venous thrombosis and cancer has been recognized for over 100 years and has a prevalence rate of $10-20 \%$ [1]. A systemic activation of blood coagulation which leads to increased tendency toward formation of blood clots is frequently present in cancer patients. Most tumor cells have constitutively active tissue factor on their surface, capable of generating thrombin in plasma. The presence of thrombin has been shown in a variety of tumor types and a clinical study demonstrated that primary thromboembolism increases the risk of overt cancer diagnosis by 3-fold within 6-12 months after thrombosis [2]. These clinical observations are in line with animal experiments where thrombin treatment of B16 melanoma tumors increases dramatically the number of lung metastases in rats [3]. Malignancy initiates a vicious cycle in which greater tumor burden supplies more thrombin that stimulates tumor growth and increases platelet-tumor interaction. The tumor-promoting effects of thrombin may be related to its pro-

Abbreviations: BAEC, bovine aortic endothelial cells; CAM, chick chorioallantoic membrane; DMF, $\mathrm{N}, \mathrm{N}$-dimethylformamide; DCM, dichloromethane; DIAD, diisopropyl azodicarboxylate; GPIIb/IIIa, glycoprotein IIb/IIIa; HMEC, human microvascular endothelial cells; MAEC, mouse aortic endothelial cells; MCF-7, a human breast cancer cell line; VEGFR2, vascular endothelial growth factor receptor 2.

* Corresponding author.

** Corresponding author. Tel.: +386147695 61; fax: +38614258031.

E-mail address: danijel.kikelj@ffa.uni-lj.si (D. Kikelj). angiogenic activity, which is thought to be mediated by activation of its protease-activated receptor (PAR-1) which leads to downstream mitogenic signaling events resulting inter alia in the expression of vascular endothelial growth factor (VEGF) in tumor cells and its tyrosine kinase receptor VEGFR2 in endothelial cells [4-6].

Thrombin stimulates the migration of tumor cells into the vasculature and, together with other tumor secreted agents, activates the endothelial cells and platelets to expose P-selectin. Weakly activated platelets and endothelial cells bind tumor cells via P-selectin exposed on their surface inducing weak tethering of tumor cells to the endothelium and platelets. Finally, a firm binding of tumor cells to platelets occurs through interaction mediated by binding of platelet integrin GPIIb/IIIa to tumor integrins via RGD motif-containing ligands, such as von Willebrand Factor (vWF) and fibronectin. These events lead to angiogenesis via thrombinstimulated synthesis and release of VEGF and other proangiogenic growth factors from tumor cells and platelets and induction of VEGFR2 synthesis in endothelial cells. Platelet-tumor aggregates protect tumor cells from natural killer cells, prolong their survival in the blood and bind more avidly to subendothelial basement membranes and matrix. Many tumor cells require platelets for the development of metastasis and it has been shown that several tumor cell lines aggregate platelets in vitro $[4,5,8]$. Targeting the aberrant growth of blood vessels, a common biological aspect of anti-angiogenic drugs [9-11], is extensively being explored in oncology in order to deprive tumors of nutrients normally delivered by blood flow [12-15]. Recent studies indicate that 
angiogenesis inhibitors, by depriving tumors of oxygen, can have an unintended effect - promotion of metastasis [16-20].

Both thrombin and integrin GPIIb/IIIa are thus important players in angiogenesis and metastasis. The thrombin inhibitor hirudin was demonstrated to inhibit angiogenesis in a chick chorioallantoic membrane assay [7] and in some models RGD-containing peptides were shown to block metastasis [5]. We have recently described novel potential dual antithrombotic compounds which comprise in the same molecule both thrombin inhibitory and fibrinogen receptor (GPIIb/IIIa) antagonistic activity due to highly overlapped thrombin inhibitor and fibrinogen receptor antagonist pharmacophores [21-23]. Knowing the interplay between cancer and thrombosis, with thrombin and platelet GPIIb/IIIa receptor as key players involved in angiogenesis and metastasis, we wanted to investigate whether our compounds with thrombin inhibitory and GPIIb/IIIa antagonistic activity are endowed with antiangiogenic activity. Small-molecule multitarget compounds with antithrombotic, antiangiogenic and possible antimetastatic activity would present an interesting synergistic approach in cancer therapy which has also been reported for phosphomannopentaose sulfate (PI-88), a multi-component mixture of phosphomannopentaose and phosphomannotetraose sulfates and related heparan sulfate mimetics [24]. The sulfated oligosaccharide PI-88 is a potent antiangiogenic and antimetastatic agent which also inhibits thrombin but does not aggregate platelets [24,25]. In this paper we (i) report on the antiangiogenic activity of two series of our multitarget compounds combining in the same molecule highly overlapped pharmacophores of thrombin inhibitors and GPIIb/IIIa antagonists and (ii) seek to establish a rough structure-activity relationship. and (iii) discuss a possible mechanism responsible for their inhibition of angiogenesis.

\section{Results and discussion}

\subsection{Chemistry}

The design and synthesis of 1,4-benzoxazine compounds represented by general structures $\mathbf{1 a}$ and $\mathbf{1 b}$ has been described recently $[22,23]$. They comprise highly integrated pharmacophores of thrombin inhibitors ( $\mathrm{a} \mathrm{P}_{1}$ benzamidine group, a $\mathrm{P}_{2}$ benzoxazine core and $\mathrm{P}_{3} \mathrm{~N}$-carboxymethyl-benzylamino or $\mathrm{N}$-oxalyl-benzylamino moieties) and GPIIb/IIIa antagonists (a benzamidine moiety separated by a 2-hydroxymethyl-6/7-methylamino-1,4-benzoxazine spacer from a carboxylate group). The preparation of nitriles $\mathbf{2 a}, \mathbf{b}$ $[22,23]$ and $[1,2,4]$ triazolo[4,3,b]pyridazine analogs $\mathbf{2 c}[26]$ has also been described (Fig. 1). The synthesis of 1,4-benzodioxine analogs $\mathbf{1 0 a}, \mathbf{b}$ and 11a,b is presented in Schemes 1 and 2. The reaction of 4nitrocatechol (3) with epichlorohydrin (4) in the presence of sodium hydrogen carbonate in $N, N$-dimethylformamide according to a published procedure [27] afforded (7-nitro-2,3-dihydrobenzo[b][1,4] dioxin-2-yl)methanol (5b) whereas the reaction of $\mathbf{3}$ with epichlorohydrin (4) using sodium hydride as a base gave the 6-nitro isomer 5a (Scheme 1). Both nitro isomers were reacted with 4hydroxybenzonitrile under Mitsunobu conditions to give ethers $\mathbf{6 a}$ and $\mathbf{6 b}$ which were reduced in the next step to amines $\mathbf{7 a}$ and $\mathbf{7 b}$ using catalytic hydrogenation over palladium on charcoal. The amines were benzylated using benzaldehyde and sodium borohydride and the resulting $N$-benzylamines $\mathbf{8 a}$ and $\mathbf{8 b}$ acylated with ethyl oxalyl chloride to give compounds $\mathbf{9 a}$ and $\mathbf{9 b}$. They afforded amidines 10a,b upon Pinner reaction, the ester group of which was hydrolyzed to the carboxylic acids 11a and 11b (Scheme 2).

The preparation of compounds $\mathbf{1 7} \mathbf{a}$ and $\mathbf{1 7} \mathbf{b}$, lacking the basic benzamidine moiety is presented in Scheme 3. The 2-(hydroxymethyl)-2H-benzo[ $b][1,4]$ oxazine derivative 12 [22] was acetylated with acetic anhydride to give ester 13 , which upon catalytic reduction to amine $\mathbf{1 4}$ and further benzylation with benzaldehyde or 3,5-difluorobenzaldehyde afforded $N$-benzylamines 15a and 15b. These were acylated with ethyl oxalyl chloride to give $N$-ethyl oxalyl derivatives $\mathbf{1 6 a}$ and $\mathbf{1 6 b}$ which were finally hydrolyzed to afford carboxylic acids $\mathbf{1 7}$ a and $\mathbf{1 7 b}$.

\subsection{Pharmacology}

\subsubsection{Inhibition of cell proliferation}

Several in vitro and in vivo assays have been developed that recapitulate different steps of the angiogenesis process, including endothelial cell proliferation, migration and tube formation [28]. We first investigated the anti-proliferative activity of 1,4benzoxazine compounds $\mathbf{1 a}$ and $\mathbf{1 b}$, nitriles $\mathbf{2 a}$ and $\mathbf{2 b}[1,2,4]$,triazolo[4,3,b]pyridazines $\mathbf{2 c}$, 1,4-benzodioxines $\mathbf{1 0}$ and $\mathbf{1 1}$, as well as compounds 16 and 17 lacking a basic $\mathrm{P}_{1}$ moiety, in two endothelial cell lines [human microvascular endothelial cells (HMEC-1) and bovine aortic endothelial cells (BAEC)] [29,30]. The results collected in Table 1 demonstrate that esters $\mathbf{1 a}$ and $\mathbf{1 b}$ inhibit the proliferation of both endothelial cell lines equally well, with $\mathrm{IC}_{50}$ values of 7- $N$-alkylamino compounds 1b1-1b4 ranging from 1.8 to $4.1 \mu \mathrm{M}$ and from 4.6 to 7.9 micromolar for $7-N$-acylamino compounds 1b5-1b8. Also the 6-substituted compounds 1a1-1a8 showed anti-proliferative activity with a trend toward more pronounced cytostatic activity of $6-\mathrm{N}$-alkylamino compounds 1a1-1a4 $\left(\mathrm{IC}_{50}\right.$ ranging from 3.8 to $6.7 \mu \mathrm{M}$ ) versus $6-N$-acylamino compounds $1 \mathbf{a 5}-\mathbf{1 a 8}$ ( $\mathrm{IC}_{50}$ ranging from 6.6 to $17.9 \mu \mathrm{M}$ ). In both endothelial cell lines the $N$-acylamino-1,4-benzodioxine compounds (S)-10a and 10b were found to be about 3-fold weaker inhibitors of cell proliferation than the corresponding 1,4-benzoxazine compounds.

$[1,2,4]$ Triazolo[4,3-b]pyridazine compounds $2 \mathbf{c}\left(\mathrm{R}^{2}=\mathrm{Et}\right)$ lacking a basic benzamidine moiety inhibited proliferation of BAEC and HMEC-1 ( IC $_{50}$ values between 33.5 and $46.0 \mu \mathrm{M}$; results not shown) although they were found to be up to 10 -fold less potent than amidines $\mathbf{1 a}$ and $\mathbf{1 b}$. The tested 6-and 7-substituted nitriles $\mathbf{2 a}$ and $\mathbf{2 b}$, showing a high similarity to amidines $\mathbf{1 a}$ and $\mathbf{1 b}$, were either inactive (i.e. compounds $\mathbf{2 a 1}$ and 2a4) or weakly active (i.e. compound 2b4) with $\mathrm{IC}_{50}$ values in the range of $24.6-49.7 \mu \mathrm{M}$. Compounds 16a and $\mathbf{1 6 b}$, lacking the basic benzamidino moiety as well, also displayed no (i.e. compound 16a) or a weak (i.e. compound 16b) inhibition of HMEC-1 and BAEC proliferation ( $\mathrm{IC}_{50}$ values of 89.4 and $59.6 \mu \mathrm{M}$ respectively), supporting the view that in the tested series of compounds a benzamidine moiety is important for antiproliferative activity. All tested carboxylic acids series (1a and 1b, 2c: $R^{2}=H$; $11 a$ and $11 b ; 17 a$ and 17b) were devoid of anti-proliferative activity $\left(\mathrm{IC}_{50}>100 \mu \mathrm{M}\right.$; results not shown), suggesting that cellular uptake, which may be significantly hampered in zwitterionic compounds, is required for antiproliferative activity.

Next, all compounds were evaluated for their capacity to inhibit the proliferation of two carcinoma cell lines [human cervical carcinoma cells (HELA) and human breast carcinoma cells (MCF-7)] (Table 1). The compounds showed comparable anti-proliferative activity in tumor cells and endothelial cells, the most active compounds being 6-N-alkylamino compounds 1a1-1a4 and 7- $\mathrm{N}$ alkylamino compounds $\mathbf{1 b 1}-\mathbf{1 b} \mathbf{4}$ with $\mathrm{IC}_{50}$ values between 3.5 and $5.3 \mu \mathrm{M}$. These data indicate that the compounds show no selectivity toward any of the tested cell types.

Several compounds not only inhibited cell growth (i.e. cytostatic action) but, at a higher concentration, also induced cell death (i.e. cytotoxic action). In particular, all 1,4-benzoxazine compounds were toxic at $100 \mu \mathrm{M}$ after 3 days in culture (not shown). Both 6-and 7- $N$-alkylamino series 1a1-1a4 and 1b1-1b4 were still toxic at $30 \mu \mathrm{M}$, whereas the respective $N$-acylamino series 1a5-1a8 and 1b5-1b8 displayed no toxicity at this 


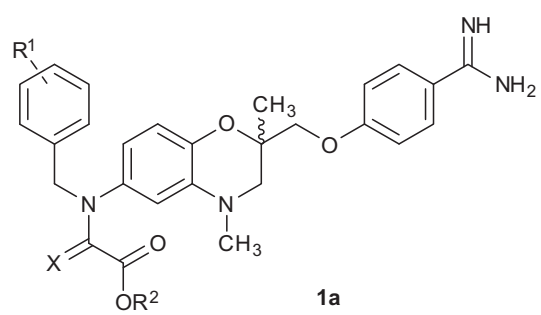<smiles>[R2]OC(=O)C([X])N(Cc1cccc([R1])c1)c1ccc2c(c1)OC(C)(COc1ccc(C(=N)N)cc1)CN2C</smiles>

$R^{1}=H ; 3-F ; 4-F ; 3,4-d i f l u o r o ; 3,5-d i f l u o r o ; R^{2}=H, E t ; X=H, H ; O$<smiles>[R]c1ccc(CN2CCN(CC(=O)OCC)CC2)cc1</smiles>

2a: substitution in position $6 ; \mathrm{R}^{1}=3-\mathrm{F} ; 3$,5-difluoro

2b: substitution in position $7 ; \mathrm{R}^{1}=4-\mathrm{F} ; 3,5$-difluoro<smiles>[R20]C(=O)C(=O)N(Cc1ccccc1)c1ccc2c(c1)O[C@@](C)(COc1ccc3nnc([R3])n3n1)CN2C</smiles>

2c: $R^{1}=H, 4-F ; 3,5$-difluoro; $R^{2}=H, E t, R^{3}=H, M e$

Fig. 1. 1,4-Benzoxazines $\mathbf{1 a}, \mathbf{1 b}$ with thrombin inhibitory and GPIIb/IIIa antagonistic activity, intermediary nitriles $\mathbf{2 a}$ and $\mathbf{2 b}$ and [1,2,4]triazolo[4,3,b]pyridazine analogs $\mathbf{2 c}$.

concentration. In contrast to benzoxazines $\mathbf{1 a}$ and $\mathbf{1 b}$ the benzodioxine compounds $(S)$-10a and $\mathbf{1 0 b}$ were not toxic at $100 \mu \mathrm{M}$ (not shown). These results highlight the contribution of the $N$-ethyl oxalyl substituent and 1,4-benzodioxine scaffold to lowering the toxicity of these compound series.

\subsubsection{Inhibition of endothelial cell migration}

Endothelial cell migration is an essential step in angiogenesis. Therefore, compounds with anti-proliferative activity (i.e. 1,4benzoxazines of $\mathbf{1 a}$ and $\mathbf{1 b}$ series, benzodioxine 10b, compounds $\mathbf{1 6} \mathbf{a}$ and $\mathbf{1 6 b}$ ) were tested for possible inhibition of endothelial cell migration in a wound closure assay [28,30]. As shown in Fig. 2, a clear dose-dependent inhibitory effect was observed for all compounds. Also here, there was a trend toward more pronounced inhibition of cell migration by the $6-\mathrm{N}$-alkylaminobenzoxazine 1a1-1a4 and 7- $N$-alkylaminobenzoxazine series 1b1-1b4 versus their acyl counterparts 1a5-1a8 and 1b5-1b8. In particular, the $N$ alkyl compounds caused a complete (or nearly complete) inhibition of MAEC migration at $30 \mu \mathrm{M}$ and still inhibited wound closure by about $50 \%$ at $10 \mu \mathrm{M}$. A higher than $40 \%$ inhibition of MAEC cell migration was still present at $3 \mu \mathrm{M}$ concentration for 1a1, 1a4, 1a5, 1b2, and $\mathbf{1 b 8}$ (Fig. 2). The most potent inhibitor of endothelial cell migration was 1b2, which showed $95 \%, 78 \%$ and $41 \%$ inhibition of cell migration at 30,10 , and $3 \mu \mathrm{M}$, respectively. Interestingly, compound 10b of the 7-N-acylaminobenzodioxine series and compounds 16a and 16b without a basic benzamidine moiety, which showed only modest anti-proliferative activities, displayed a potent inhibition of MAEC migration at $30 \mu \mathrm{M}$ (more than $80 \%$ inhibition) and $10 \mu \mathrm{M}$ (more than $40 \%$ inhibition) (Fig. 2).

\subsubsection{Inhibition of tube formation}

One of the most specific tests for angiogenesis is the matrigel tube formation assay which measures the ability of endothelial cells to form three-dimensional structures (tubes) [30,31]. Among the compounds tested at 30 and $10 \mu \mathrm{M}$ concentration, 6- $\mathrm{N}$-alkylaminobenzoxazine derivatives 1a1-1a4 as well as 7- $\mathrm{N}$-alkylaminobenzoxazine derivatives 1b1-1b4 completely inhibited tube formation at $30 \mu \mathrm{M}$ and were weakly active or inactive at $10 \mu \mathrm{M}$. The corresponding $N$-acylamino compounds 1a5-1a8 and 1b5$\mathbf{1 b 8}$ as well as the $7-N$-acylaminobenzodioxine derivative $\mathbf{1 0 b}$,
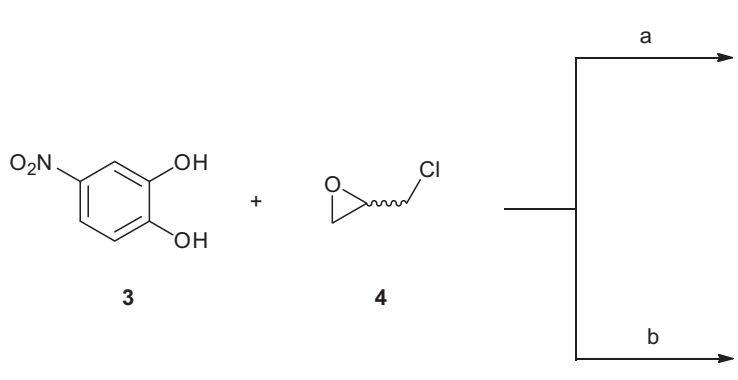<smiles>O=[N+]([O-])c1ccc2c(c1)O[C@H](CO)CO2</smiles>

$5 b$<smiles>O=[N+]([O-])c1ccc2c(c1)OC[C@@H](CO)O2</smiles> 


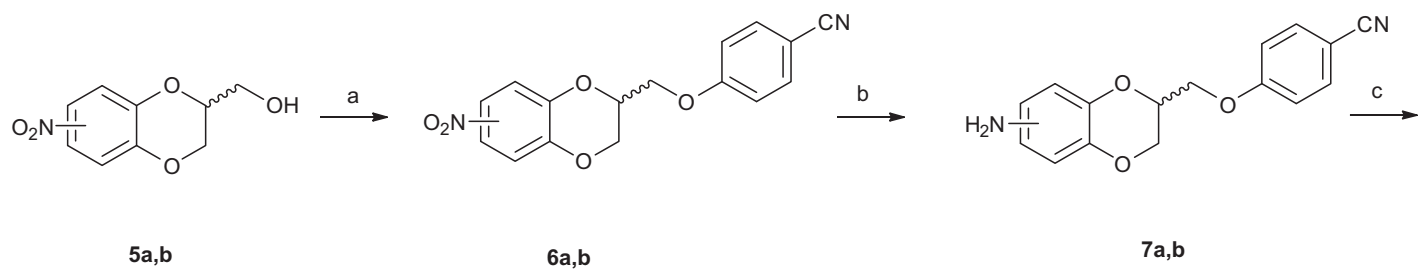<smiles>CCOC(=O)C(=O)N(Cc1ccccc1)Cc1ccc2c(c1)OC[C@@H](COc1ccc(C#N)cc1)O2</smiles><smiles>CCOC(=O)C(=O)N(CCN(Cc1ccccc1)C(=O)C(=O)O)Cc1ccccc1</smiles>

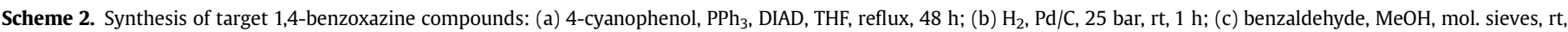
$12 \mathrm{~h}$, then $\mathrm{NaBH}_{4}, 1 \mathrm{~h}$; (d) ethyl oxalyl chloride, $\mathrm{Et}_{3} \mathrm{~N}, \mathrm{DCM}, \mathrm{rt}, 2 \mathrm{~h}$; (e) $\mathrm{HCl}_{\mathrm{g}}$, EtOH, $0{ }^{\circ} \mathrm{C}, 30 \mathrm{~min}, \mathrm{rt}, 24 \mathrm{~h}$, then $\mathrm{CH}_{3} \mathrm{COONH}_{4}, \mathrm{rt} 24 \mathrm{~h}$; (f) $1 \mathrm{M} \mathrm{LiOH}, \mathrm{THF} / \mathrm{MeOH}, \mathrm{rt}, 2 \mathrm{~h}$.

being less toxic than the corresponding $N$-alkylamino compounds exhibited a concentration-dependent inhibition of tube formation. Interestingly, compounds $\mathbf{1 6 a}$ and $\mathbf{1 6 b}$, lacking a basic benzamidino moiety also inhibited tube formation at 100 and $30 \mu \mathrm{M}$ (Fig. 3).

\subsubsection{Inhibition of angiogenesis in the chick chorioallantoic} membrane (CAM) assay

The CAM assay is an in vivo test in which potential inhibitors of angiogenesis are assessed by their effect on normal vascular development in chick embryos [28-30]. Both 6-and 7- $\mathrm{N}$-alkylamino as well as 6 -and $7-\mathrm{N}$-acylamino esters of the benzoxazine series (1a, 1b; $\left.R_{2}=E t\right)$ and $N$-acylamino esters of the of the benzodioxine series $((S)$-10a, 10b) were found to be potent inhibitors of angiogenesis in the CAM assay at $250 \mathrm{nmol} /$ disc, while in the same experiment the corresponding carboxylic acids $\left(\mathbf{1 a}, \mathbf{1} \mathbf{b} ; \mathrm{R}_{2}=\mathrm{H}\right.$ and 11a, 11b) were devoid of angiogenesis inhibiting activity (data not shown). The observed inhibition of angiogenesis may be attributed to thrombin inhibition, since compounds 1a, 1b, $(S)-\mathbf{1 0 a}$, and 10b are all moderate to potent thrombin inhibitors with $K_{\mathrm{i}}$ values in the range of $18 \mathrm{nM}$ to $5.05 \mu \mathrm{M}$ [23] and inhibition of angiogenesis in chick chorioallantoic membrane by the thrombin inhibitor hirudin has been reported [7]. Compounds of the carboxylic acids series<smiles>CN1CC(C)(CO)Oc2cc([N+](=O)[O-])ccc21</smiles>

12<smiles>CN1CC(C)(CO)Oc2cc(NCc3cc#[R]cc3)ccc21</smiles>

15a $R^{1}=H$

$15 \mathrm{~b} \quad \mathrm{R}^{1}=3,5$-difluoro<smiles>CC(=O)OCC1(C)CN(C)c2ccc([N+](=O)[O-])cc2O1</smiles>

13<smiles>CC(=O)OCC1(C)CN(C)c2ccc(N)cc2O1</smiles>

14

Scheme 3. Reagents and conditions: (a) acetic anhydride, $100{ }^{\circ} \mathrm{C}, 5 \mathrm{~h}$; (b) $\mathrm{H}_{2}, \mathrm{Pd} / \mathrm{C}, 25 \mathrm{bar}, \mathrm{rt}, 1 \mathrm{~h}$; (c) benzaldehyde, MeOH, mol. sieves, rt, $12 \mathrm{~h}$, then $\mathrm{NaBH}{ }_{4}, 1 \mathrm{~h}$; (d) $3,5-$ difluorobenzaldehyde, MeOH, mol. sieves, rt, 12 h, then $\mathrm{NaBH}_{4}, 1$ h; (e) ethyl oxalyl chloride, Et 3 N, DCM, rt, 2 h; (f) 1M LiOH, THF/MeOH, rt, 2 h. 
Table 1

Antiproliferative activity in HMEC-1, BAEC, HELA and MCF-7 cell lines. Mean \pm SD are shown.

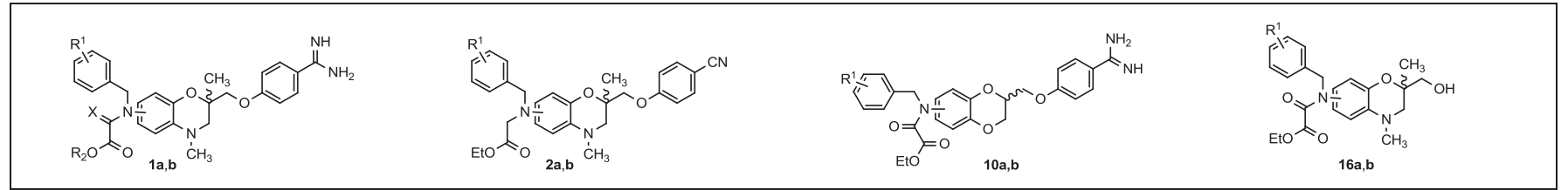

\begin{tabular}{|c|c|c|c|c|c|c|c|c|}
\hline $\begin{array}{l}\text { Comp. } \\
\text { No. }\end{array}$ & $\begin{array}{l}\text { Subst. } \\
\text { Position }\end{array}$ & $\mathrm{R}^{1}$ & $X$ & $\mathrm{R}^{2}$ & $\begin{array}{l}\text { HMEC-1 } \\
\mathrm{IC}_{50}(\mu \mathrm{M})\end{array}$ & $\begin{array}{l}\text { BAEC IC }_{50} \\
(\mu \mathrm{M})\end{array}$ & $\begin{array}{l}\text { HELA IC } 50 \\
(\mu \mathrm{M})\end{array}$ & $\begin{array}{l}\text { MCF-7 } \\
\mathrm{IC}_{50}(\mu \mathrm{M})\end{array}$ \\
\hline $1 \mathrm{a} 1$ & 6 & $3-F$ & $\mathrm{H}, \mathrm{H}$ & Et & $6.0 \pm 0.1$ & $3.9 \pm 0.1$ & $4.6 \pm 0.8$ & $4.2 \pm 0.8$ \\
\hline $1 \mathrm{a} 2$ & 6 & $4-\mathrm{F}$ & $\mathrm{H}, \mathrm{H}$ & Et & $6.0 \pm 1.1$ & $3.8 \pm 0.5$ & $4.8 \pm 0.9$ & $4.1 \pm 0.6$ \\
\hline $1 a 3$ & 6 & $3-F, 4-F$ & $\mathrm{H}, \mathrm{H}$ & Et & $4.2 \pm 0.4$ & $4.1 \pm 0.3$ & $4.8 \pm 0.9$ & $3.9 \pm 0.7$ \\
\hline $1 a 4$ & 6 & $3-F, 5-F$ & $\mathrm{H}, \mathrm{H}$ & Et & $6.7 \pm 0.0$ & $4.0 \pm 0.2$ & $4.5 \pm 1.1$ & $4.5 \pm 0.3$ \\
\hline $1 \mathrm{a} 5$ & 6 & $3-F$ & $\mathrm{O}$ & Et & $7.7 \pm 1.1$ & $18 \pm 4$ & $20 \pm 4$ & $6.5 \pm 0.5$ \\
\hline $1 \mathrm{a} 6$ & 6 & $4-\mathrm{F}$ & 0 & Et & $8.4 \pm 0.1$ & $6.6 \pm 1.4$ & $14 \pm 7$ & $5.5 \pm 0.8$ \\
\hline $1 a 7$ & 6 & $3-F, 4-F$ & 0 & Et & $8.3 \pm 0.8$ & $7.4 \pm 1.6$ & $14 \pm 8$ & $6.3 \pm 1.0$ \\
\hline $1 a 8$ & 6 & $3-F, 5-F$ & $\mathrm{O}$ & Et & $7.8 \pm 1.1$ & $11 \pm 6$ & $6.9 \pm 2.7$ & $5.2 \pm 1.1$ \\
\hline 1b1 & 7 & $3-\mathrm{F}$ & $\mathrm{H}, \mathrm{H}$ & Et & $2.6 \pm 0.1$ & $4.1 \pm 0.3$ & $4.5 \pm 0.5$ & $3.9 \pm 0.4$ \\
\hline $1 \mathrm{~b} 2$ & 7 & $4-\mathrm{F}$ & $\mathrm{H}, \mathrm{H}$ & Et & $2.9 \pm 0.7$ & $2.9 \pm 0.8$ & $4.0 \pm 0.1$ & $5.3 \pm 0.2$ \\
\hline $1 \mathrm{~b} 3$ & 7 & $3-\mathrm{F}, 4-\mathrm{F}$ & $\mathrm{H}, \mathrm{H}$ & Et & $2.5 \pm 0.1$ & $4.0 \pm 0.7$ & $4.1 \pm 0.2$ & $4.0 \pm 0.3$ \\
\hline $1 b 4$ & 7 & $3-F, 5-F$ & $\mathrm{H}, \mathrm{H}$ & Et & $1.8 \pm 0.1$ & $4.1 \pm 0.8$ & $4.9 \pm 0.5$ & $3.5 \pm 0.9$ \\
\hline $1 b 5$ & 7 & $3-F$ & $\mathrm{O}$ & Et & $7.9 \pm 0.6$ & $6.5 \pm 0.1$ & $7.7 \pm 0.3$ & $3.8 \pm 1.9$ \\
\hline $1 \mathrm{~b} 6$ & 7 & $4-\mathrm{F}$ & 0 & Et & $7.6 \pm 0.4$ & $6.9 \pm 0.5$ & $14 \pm 4$ & $6.3 \pm 0.6$ \\
\hline $1 b 7$ & 7 & $3-\mathrm{F}, 4-\mathrm{F}$ & 0 & Et & $6.7 \pm 0.4$ & $4.9 \pm 1.0$ & $11 \pm 4$ & $5.8 \pm 0.8$ \\
\hline $1 \mathrm{b8}$ & 7 & $3-F, 5-F$ & 0 & Et & $6.8 \pm 0.4$ & $4.6 \pm 0.3$ & $6.6 \pm 0.5$ & $2.9 \pm 0.4$ \\
\hline $2 a 1$ & 6 & $3-F$ & - & - & $>100$ & $>100$ & $>100$ & $>100$ \\
\hline $2 a 4$ & 6 & $3-F, 5-F$ & - & - & $>100$ & $>100$ & $>100$ & $>100$ \\
\hline $2 \mathbf{b} 2$ & 7 & $4-\mathrm{F}$ & - & - & $>100$ & $50 \pm 7$ & $>100$ & $>100$ \\
\hline $2 b 4$ & 7 & $3-F, 5-F$ & - & - & $49 \pm 1$ & $25 \pm 9$ & $>100$ & $54 \pm 4$ \\
\hline $10 \mathbf{a}(S)$ & 6 & $\mathrm{H}$ & - & - & $24 \pm 1$ & $12 \pm 0$ & $19 \pm 2$ & $9.5 \pm 2.3$ \\
\hline $10 b$ & 7 & $\mathrm{H}$ & - & - & $22 \pm 3$ & $8.5 \pm 0.2$ & $8.0 \pm 3.1$ & $8.7 \pm 2.7$ \\
\hline $16 a$ & 7 & $\mathrm{H}$ & - & - & $>100$ & $>100$ & $>100$ & $>100$ \\
\hline $16 b$ & 7 & $3-F, 5-F$ & - & - & $89 \pm 7$ & $60 \pm 9$ & $44 \pm 6$ & $45 \pm 4$ \\
\hline SU5416 & - & - & - & - & $15 \pm 9$ & $8.3 \pm 2.2$ & $20 \pm 6$ & $1.9 \pm 1.5$ \\
\hline
\end{tabular}

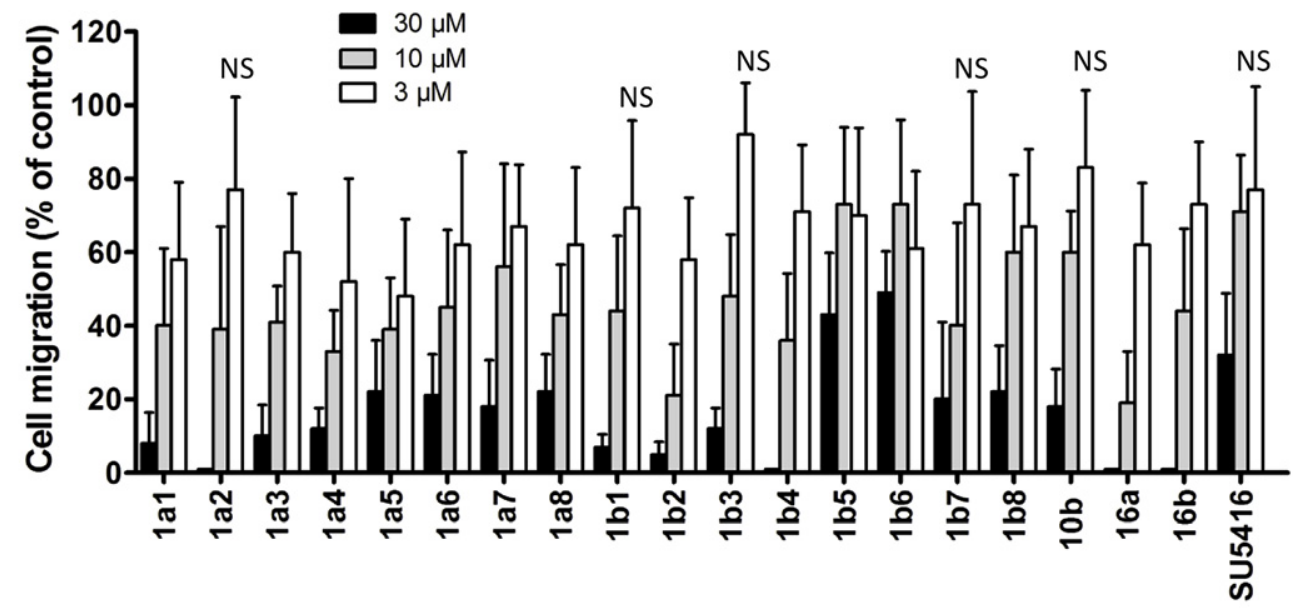

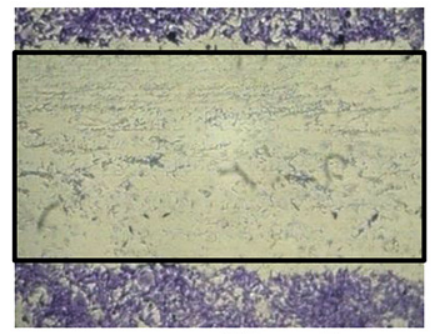

Control $(t=0)$

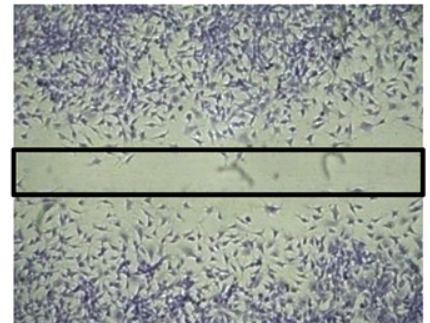

Control $(t=5 \mathrm{~h})$

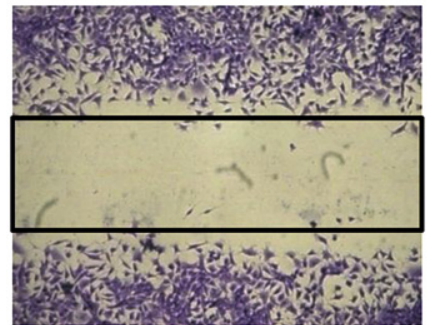

$1 \mathrm{a} 4(10 \mu \mathrm{M})$

Fig. 2. MAEC wound closure (migration) assay; results are the mean $( \pm \mathrm{SD})$ of $2-4$ independent experiments. All data $p<0.05$, except NS (not significant). 

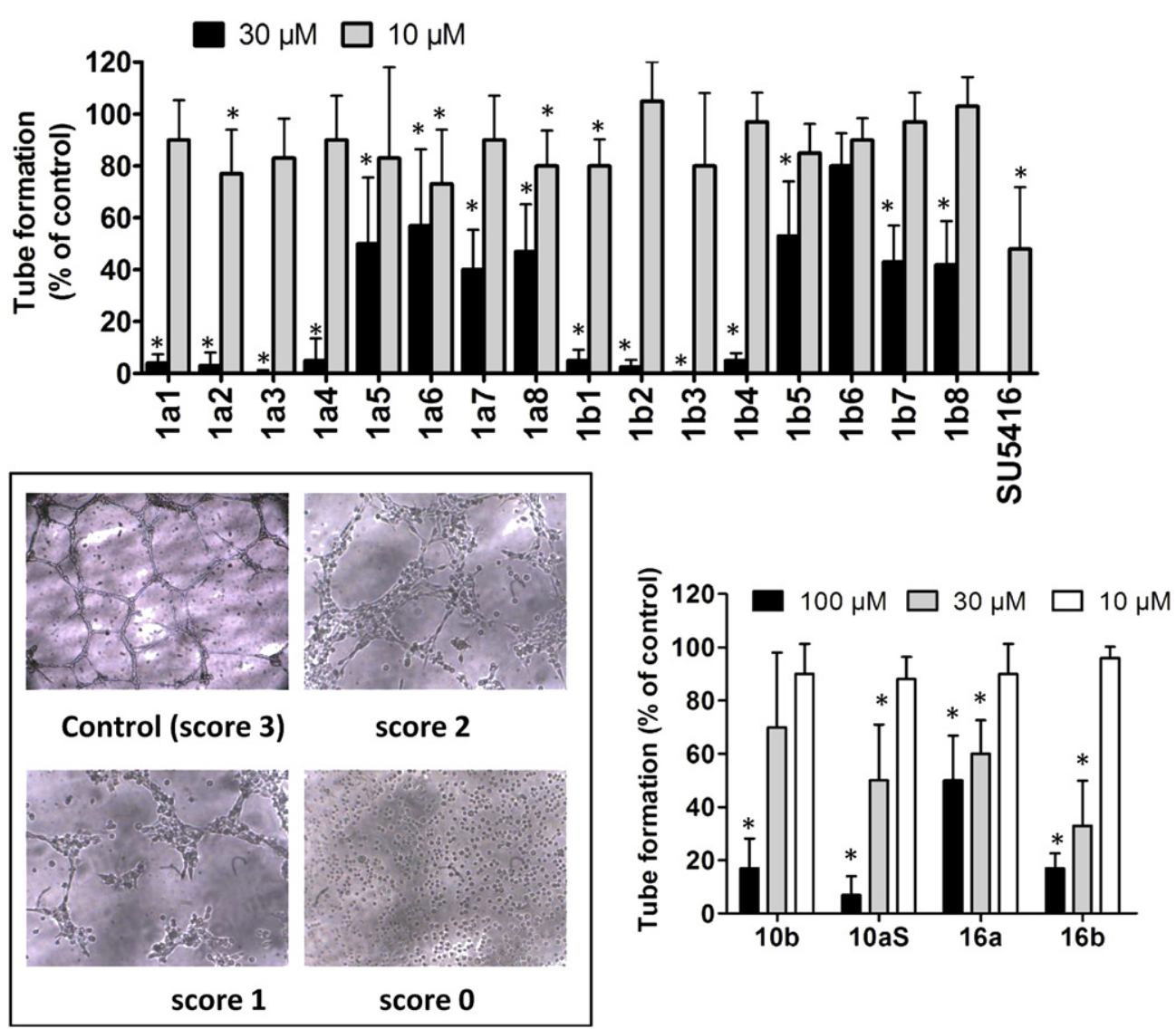

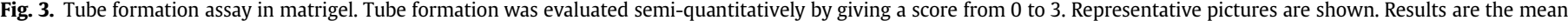
$( \pm \mathrm{SD})$ of $2-4$ independent experiments. ${ }^{*} p<0.05$.
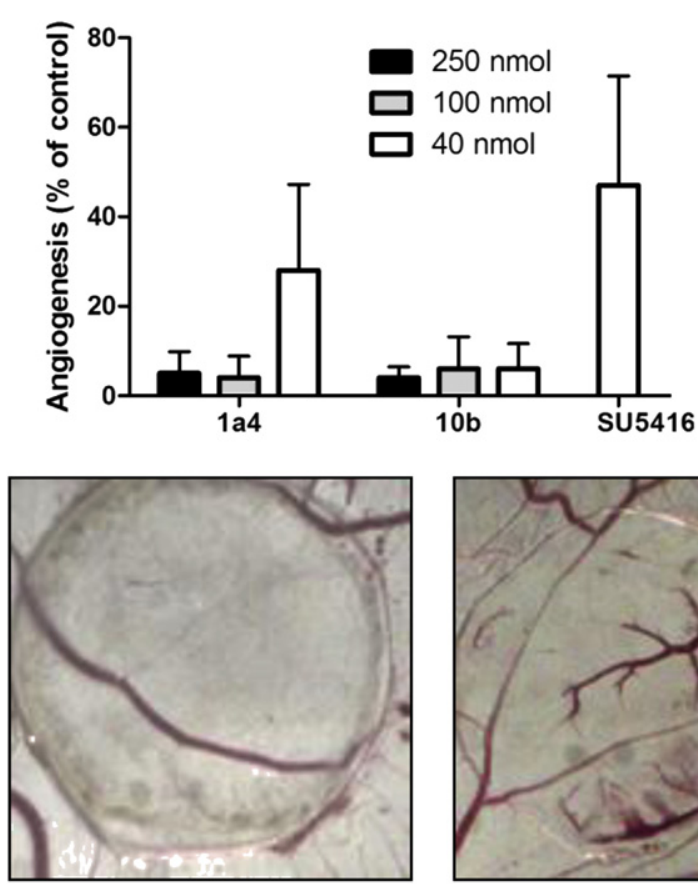

$10 \mathrm{~b}(100 \mathrm{nmol})$

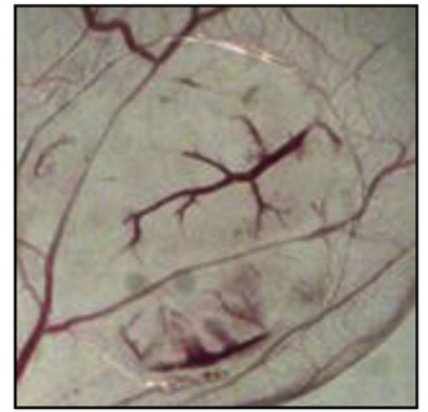

$1 \mathrm{a} 4(40 \mathrm{nmol})$

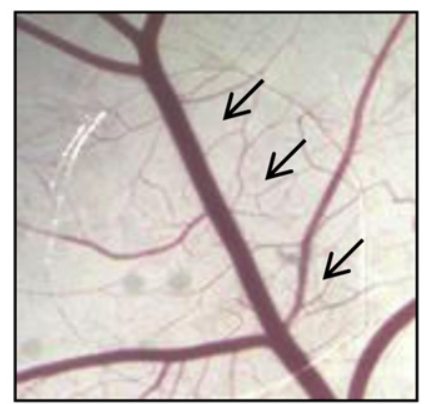

Control

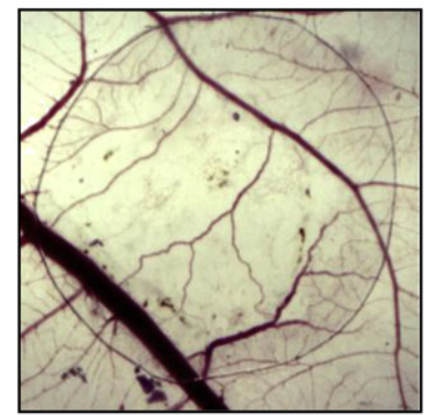

SU5416 $(40 \mathrm{nmol})$

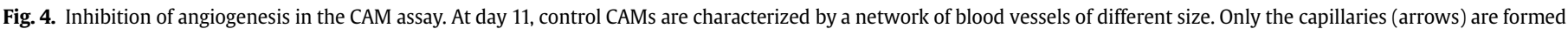

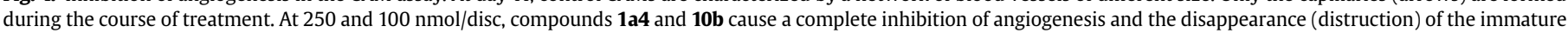

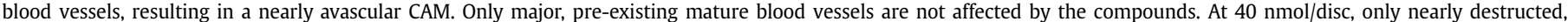

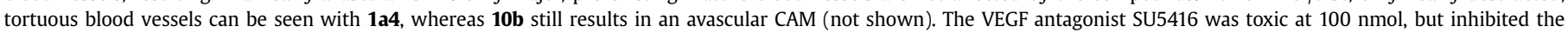
formation of new blood vessels at $40 \mathrm{nmol} /$ disc. $n=6-12, p<0.05$. Mean \pm SD are shown. 
(1a, 1b; $\mathrm{R}_{2}=\mathrm{H}$ and 11a, 11b), which are also thrombin inhibitors, although generally an order of magnitude less potent than the corresponding esters [23], were devoid of anti-angiogenic activity in the CAM assay (data not shown), again confirming that cell penetration, which is expected to be impaired in zwitterionic carboxylic acids, is required for biological activity of these compounds.

Two compounds of each series (i.e. 1a4 of the benzoxazine series and 10b of the benzodioxine series) were selected for further analysis at various concentrations. Compound 1a4 $\left(K_{\mathrm{i}}\right.$ (thrombin) $\left.=0.95 \mu \mathrm{M}\right)$ caused a complete inhibition of angiogenesis and the degradation of immature, existing vessels at 250, 100 and $40 \mathrm{nmol} / \mathrm{disc}$, and destruction of vessels with bleeding at $20 \mathrm{nmol} /$ disc. Also 10b $\left(K_{\mathrm{i}}\right.$ (thrombin) $\left.=0.178 \mu \mathrm{M}\right)$ completely abrogated CAM vascularization at 250 and $100 \mathrm{nmol} / \mathrm{disc}$ and vascular destruction at $40 \mathrm{nmol} / \mathrm{disc}$. Only major, pre-existing mature blood vessels were not affected by the compounds (Fig. 4). Both compounds were more potent than the reference compound SU5416, the latter being toxic at $100 \mathrm{nmol} / \mathrm{egg}$, and reduced angiogenesis by $47 \%$ at $40 \mathrm{nmol} / \mathrm{disc}$.

In summary, esters of 1,4-benzoxazine and 1,4-benzodioxine series were found to be potent inhibitors of angiogenesis in CAM assay. However, since complete inhibition of angiogenesis was elicited by potent thrombin inhibitors such as $\mathbf{1 b 8}\left(K_{\mathrm{i}}\right.$ (thrombin) $=18 \mathrm{nM}$ ) as well as by weak thrombin inhibitors such as $1 \mathrm{a} 4\left(K_{\mathrm{i}}\right.$ (thrombin) $\left.=0.95 \mu \mathrm{M}\right)[23]$ a question arises as to whether other effects, besides thrombin inhibition, might contribute to their anti-angiogenic activity.

\subsubsection{Radiometric protein kinase assay}

In order to verify some of the best results obtained by docking to VEGFR2 variants, compounds $\mathbf{1 a 4}\left(\mathrm{R}^{2}=\mathrm{H}\right)$ and $\mathbf{1 a 5}$ were tested for inhibition of VEGFR-2 kinase in a radiometric protein kinase assay in which inhibition of poly(Glu,Tyr) 4:1 substrate phosphorylation by isolated human recombinant VEGFR2 tyrosin kinase was measured [32]. Both compounds, screened as racemic mixtures, were found to be micromolar inhibitors with $\mathrm{IC}_{50}$ values of $22.5 \mu \mathrm{M}$ for $1 \mathrm{a4}\left(\mathrm{R}^{2}=\mathrm{H}\right)$ and $80.0 \mu \mathrm{M}$ for $\mathbf{1 a 5}$. On the other side, it has been proven by $\mathrm{IC}_{50}$ determination that compound $\mathbf{1 a 4}\left(\mathrm{R}^{2}=\mathrm{H}\right)$ inhibits VEGFR2 kinase in concentration depending manner [32]. From these results we can assume that, besides inhibiting of thrombin, the inhibition of angiogenesis observed by compounds $\mathbf{1}$ and $\mathbf{1 0}$ in the CAM assay, could to some extent also be due to slowing down of VEGFR2 activity.

\section{Conclusion}

In conclusion, 1,4-benzoxazine and 1,4-benzodioxine compounds $\mathbf{1}$ and 10, which combine thrombin inhibitory and GPIIb/IIIa antagonistic activity in one molecule, were identified as potent inhibitors of angiogenesis in their ester form. The corresponding carboxylic acids were devoid of antiangiogenic activity, most probably due to their insufficient entry into the cell. Although thrombin inhibition remains the most probable explanation for their inhibition of angiogenesis by compounds $\mathbf{1}$ and $\mathbf{1 0}$, other targets such as VEGFR2 might be involved. Future experiments should reveal the exact mechanism of action and potential antitumor and/or anti-metastatic activity of these compounds.

\section{Experimental section}

\subsection{General}

Chemicals were obtained from Acros, Aldrich Chemical Co. and Fluka and used without further purification. The synthesis of compound (S)-10a is described in ref. [23]b. Analytical TLC was performed on silica gel Merck $60 \mathrm{~F}_{254}$ plates $(0.25 \mathrm{~mm})$, using visualization with ultraviolet light. Column chromatography was carried out on silica gel 60 (particle size 240-400 mesh). Melting points were determined on a Reichert hot stage microscope and are uncorrected. ${ }^{1} \mathrm{H}$ NMR and ${ }^{13} \mathrm{C}$ NMR spectra were recorded on a $400 \mathrm{MHz}$ Bruker AVANCE III spectrometer in DMSO- $d_{6}$ solution with TMS as the internal standard. The following abbreviations were used to describe peak patterns wherever appropriate: $\mathrm{br}=$ broad, $\mathrm{d}=$ doublet, $\mathrm{dd}=$ doublet of doublet, $\mathrm{t}=$ triplet, $\mathrm{q}=$ quartet, and $\mathrm{m}=$ multiplet. IR spectra were recorded on a Perkin-Elmer 1600 FT-IR spectrometer. Microanalyses were performed on a Perkin-Elmer C, H, N Analyzer 240 C. Analyses indicated by the symbols of the elements were within $\pm 0.4 \%$ of the theoretical values. Mass spectra were obtained using a VGAnalytical Autospec Q mass spectrometer. HPLC Analyses were performed on an Agilent Technologies HP 1100 instrument with G1365B UV-VIS detector ( $254 \mathrm{~nm}$ ), using an Eclips Plus C18 column $(4.6 \times 150 \mathrm{~mm})$ at flow rate $1 \mathrm{~mL} / \mathrm{min}$. The eluent was a mixture of $0.1 \%$ TFA in water (A) and methanol (B). Gradient was $40 \%$ B to $80 \%$ B in $15 \mathrm{~min}$. All of the compounds reported in this paper have a purity $>95 \%$ (HPLC). Purifications of final esters by reverse phase column chromatography were performed using a Flash Purification System ISOLERA $^{\mathrm{TM}}$. The eluent was a mixture of $0.1 \%$ TFA in water $(A)$ and methanol (B). Gradient was $40 \%$ B to $80 \%$ B in 30 column volumes.

\subsubsection{4-((6-Nitro-2,3-dihydrobenzo[b][1,4]dioxin-2-yl)methoxy)} benzonitrile $(\mathbf{6 a})$

4-Cyanophenol (986 mg, $8.28 \mathrm{mmol}$ ) and triphenylphosphine (3.95 g, $15.06 \mathrm{mmol}$ ) were added to a solution of (6-nitro-2,3dihydrobenzo $[b] \quad[1,4]$ dioxin-2-yl)methanol (5a) (1.59 g, $7.53 \mathrm{mmol}$ ) in anhydrous tetrahydrofurane $(50 \mathrm{~mL})$. Diisopropyl azodicarboxylate (DIAD) (3.05 g, $15.06 \mathrm{mmol}$ ) dissolved in $10 \mathrm{~mL}$ anhydrous THF was added dropwise at $0{ }^{\circ} \mathrm{C}$, the solution was stirred afterward for $30 \mathrm{~min}$ at $0^{\circ} \mathrm{C}$, and then heated to reflux for $48 \mathrm{~h}$. The reaction mixture was evaporated in vacuo to dryness and the residue purified by column chromatography on silica gel (hexane:ethyl acetate $=2: 1$ ). A yellow oil obtained was recrystallized from methanol to give $1.30 \mathrm{~g}$ (yield $55 \%$ ) of pale yellow crystals; $\mathrm{mp}$ 171-174 ${ }^{\circ} \mathrm{C} ;{ }^{1} \mathrm{H}$ NMR (400 MHz, DMSO- $d_{6}$ ): $\delta$ ppm 4.33 (dd, $J=11.7$, $\left.7.3 \mathrm{~Hz}, 1 \mathrm{H}, 3-\mathrm{CH}_{2}\right), 4.38$ (dd, $\left.J=11.1,5.6 \mathrm{~Hz}, 1 \mathrm{H}, \mathrm{CH}_{2} \mathrm{O}\right), 4.45$ (dd, $\left.J=11.1,3.7 \mathrm{~Hz}, 1 \mathrm{H}, \mathrm{CH}_{2} \mathrm{O}\right), 4.62\left(\mathrm{dd}, J=11.7,2.5 \mathrm{~Hz}, 1 \mathrm{H}, 3-\mathrm{CH}_{2}\right.$ ), $4.72-4.78(\mathrm{~m}, 1 \mathrm{H}, 2-\mathrm{CH}), 7.15-7.28\left(\mathrm{~m}, 3 \mathrm{H}, \mathrm{Ar}-\mathrm{H}^{8}, \mathrm{Ar}-\mathrm{H}^{2^{\prime}}, \mathrm{Ar}-\mathrm{H}^{6^{\prime}}\right)$, 7.79-7.88 (m, 4H, $\left.\mathrm{Ar}-\mathrm{H}^{5}, \mathrm{Ar}-\mathrm{H}^{7}, \mathrm{Ar}-\mathrm{H}^{3^{\prime}}, \mathrm{Ar}-\mathrm{H}^{5^{\prime}}\right) ;{ }^{13} \mathrm{C} \mathrm{NMR}$ (101 MHz, DMSO- $\left.d_{6}\right)$ : $\delta$ ppm 65.0 (C-3), $66.5\left(\mathrm{CH}_{2} \mathrm{O}\right), 71.4(\mathrm{C}-2)$, 103.4 (C-4'), 112.7 (C-7), 115.7 (C-2', C-6'), 117.5, 117.6 (C-5, C-8), 119.0 (CN), 134.2 (C-3', C-5'), 141.2 (C-6), 142.4, 149.0 (C-4a, C-8a), $161.4\left(\mathrm{C}-1^{\prime}\right)$; HRMS (ESI) $m / z$ calcd for $\mathrm{C}_{16} \mathrm{H}_{13} \mathrm{~N}_{2} \mathrm{O}_{5}[\mathrm{M}+\mathrm{H}]^{+}$ 313.0824, found 313.0814; IR (KBr, $\left.v, \mathrm{~cm}^{-1}\right)$ : 2227, 1603, 1514, 1349, 1256, 1174, 839; HPLC: $100 \%, \mathrm{t}_{\mathrm{r}} 16.0 \mathrm{~min}$.

\subsubsection{4-((7-Nitro-2,3-dihydrobenzo[b][1,4]dioxin-2-yl)methoxy) benzonitrile (6b)}

Compound $\mathbf{6 b}$ was prepared from $\mathbf{5 b}(1.59 \mathrm{~g}, 7.53 \mathrm{mmol})$ and 4cyanophenol (986 $\mathrm{mg}, 8.28 \mathrm{mmol}$ ) according to the procedure described above for the synthesis of $\mathbf{6 a}$; pale yellow crystals; yield $1.00 \mathrm{~g}(43 \%) ; \mathrm{mp} 169-172{ }^{\circ} \mathrm{C} ;{ }^{1} \mathrm{H}$ NMR $\left(400 \mathrm{MHz}\right.$, DMSO- $\left.d_{6}\right): \delta \mathrm{ppm}$ $4.33\left(\mathrm{dd}, J=11.7,7.3 \mathrm{~Hz}, 1 \mathrm{H}, 3-\mathrm{CH}_{2}\right), 4.38(\mathrm{dd}, J=11.1,5.7 \mathrm{~Hz}, 1 \mathrm{H}$, $\mathrm{CH}_{2} \mathrm{O}$ ), 4.45 (dd, $\left.J=11.1,3.7 \mathrm{~Hz}, 1 \mathrm{H}, \mathrm{CH}_{2} \mathrm{O}\right), 4.62(\mathrm{dd}, J=11.7,2.5 \mathrm{~Hz}$, $\left.1 \mathrm{H}, 3-\mathrm{CH}_{2}\right), 4.68-4.81(\mathrm{~m}, 1 \mathrm{H}, 2-\mathrm{CH}), 7.14-7.27\left(\mathrm{~m}, 3 \mathrm{H}, \mathrm{Ar}-\mathrm{H}^{5}, \mathrm{Ar}-\right.$ $\left.\mathrm{H}^{2^{\prime}}, \mathrm{Ar}-\mathrm{H}^{6^{\prime}}\right), 7.76-7.86\left(\mathrm{~m}, 4 \mathrm{H}, \mathrm{Ar}-\mathrm{H}^{6}, \mathrm{Ar}-\mathrm{H}^{8}, \mathrm{Ar}-\mathrm{H}^{3^{\prime}}, \mathrm{Ar}-\mathrm{H}^{5^{\prime}}\right) ;{ }^{13} \mathrm{C}$ NMR (101 MHz, DMSO- $\left.d_{6}\right): \delta$ ppm $64.9(\mathrm{C}-3), 66.5\left(\mathrm{CH}_{2} \mathrm{O}\right), 71.4(\mathrm{C}-$ 2), $103.4\left(\mathrm{C}-4^{\prime}\right), 112.7$ (C-6), $115.7\left(\mathrm{C}-2^{\prime}, \mathrm{C}-6^{\prime}\right), 117.5,117.6$ (C-5, C-8),

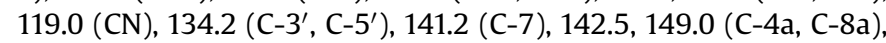
$161.4\left(\mathrm{C}-1^{\prime}\right)$; HRMS (ESI) $m / z$ calcd for $\mathrm{C}_{16} \mathrm{H}_{13} \mathrm{~N}_{2} \mathrm{O}_{5}[\mathrm{M}+\mathrm{H}]^{+}$ 313.0824, found 313.0828; IR $\left(\mathrm{KBr}, v, \mathrm{~cm}^{-1}\right)$ : 2225, 1600, 1504, 1349, 1251, 820; HPLC: 100\%, tr 16.0 min. 
4.1.3. 4-((6-(Benzylamino)-2,3-dihydrobenzo[b][1,4]dioxin-2-yl) methoxy)benzonitrile ( $8 \boldsymbol{a})$

A mixture of compound $\mathbf{6 a}(1.10 \mathrm{~g}, 3.52 \mathrm{mmol})$ and $10 \% \mathrm{Pd} / \mathrm{C}$ $(110 \mathrm{mg})$ in methanol $(100 \mathrm{~mL})$ was stirred in a hydrogenator (25 bar) for $1 \mathrm{~h}$ at room temperature. The catalyst was filtered off and the solvent evaporated in vacuo to give amine $7 \mathbf{a}(890 \mathrm{mg}, 90 \%)$ of which was used in the next step without purification. The crude amine $7 \mathbf{a}$ (890 mg, $3.15 \mathrm{mmol}$ ), benzaldehyde (334 mg, $3.15 \mathrm{mmol}$ ) and molecular sieves ( $3 \AA$ ) were mixed in methanol $(50 \mathrm{~mL})$ under $\mathrm{Ar}$ atmosphere and the mixture was stirred at room temperature for $12 \mathrm{~h}$, until the aldimine formation was completed. The reaction mixture was carefully treated with solid $\mathrm{NaBH}_{4}(191 \mathrm{mg}$, $5.04 \mathrm{mmol}$ ) and stirred for additional $1 \mathrm{~h}$. After filtration and evaporation of solvent in vacuo, a crude residue was dissolved in dichloromethane $(50 \mathrm{~mL})$ and washed successively with saturated solution of $\mathrm{NaHCO}_{3}(3 \times 50 \mathrm{~mL})$ and brine $(1 \times 50 \mathrm{~mL})$. The organic solution was dried over $\mathrm{Na}_{2} \mathrm{SO}_{4}$ and the solvent evaporated under reduced pressure. The oily product was purified by column chromatography using dichloromethane as eluent to obtain $563 \mathrm{mg}$ of 8a as pale yellow crystals; yield $43 \%$ (from 6a); mp $88-91{ }^{\circ} \mathrm{C} ;{ }^{1} \mathrm{H}$ NMR (400 MHz, DMSO- $d_{6}$ ): $\delta$ ppm $4.00(\mathrm{dd}, J=11.4,7.2 \mathrm{~Hz}, 1 \mathrm{H}$, $\left.3-\mathrm{CH}_{2}\right), 4.18\left(\mathrm{~d}, J=5.9 \mathrm{~Hz}, 2 \mathrm{H}, \mathrm{PhCH}_{2}\right), 4.18-4.31\left(\mathrm{~m}, 3 \mathrm{H}, 3-\mathrm{CH}_{2}\right.$, $\left.\mathrm{CH}_{2} \mathrm{O}\right), 4.40-4.51(\mathrm{~m}, 1 \mathrm{H}, 2-\mathrm{CH}), 5.93(\mathrm{t}, J=5.9 \mathrm{~Hz}, 1 \mathrm{H}, \mathrm{NH}), 6.07$ $\left(\mathrm{d}, J=2.6 \mathrm{~Hz}, 1 \mathrm{H}, \mathrm{Ar}-\mathrm{H}^{5}\right), 6.15\left(\mathrm{dd}, J=8.7,2.6 \mathrm{~Hz}, 1 \mathrm{H}, \mathrm{Ar}-\mathrm{H}^{7}\right), 6.62$ $\left(\mathrm{d}, J=8.7 \mathrm{~Hz}, 1 \mathrm{H}, \mathrm{Ar}-\mathrm{H}^{8}\right), 7.16\left(\mathrm{~d}, J=9.0 \mathrm{~Hz}, 2 \mathrm{H}, \mathrm{Ar}-\mathrm{H}^{2^{\prime}}, \mathrm{Ar}-\mathrm{H}^{6^{\prime}}\right)$, $7.18-7.26(\mathrm{~m}, 1 \mathrm{H}, \mathrm{Ph}), 7.27-7.35(\mathrm{~m}, 4 \mathrm{H}, \mathrm{Ph}), 7.78$ (d, $J=9.0 \mathrm{~Hz}$, $\left.2 \mathrm{H}, \mathrm{Ar}-\mathrm{H}^{3^{\prime}}, \mathrm{Ar}-\mathrm{H}^{5^{\prime}}\right) ;{ }^{13} \mathrm{C}$ NMR (101 MHz, DMSO-d $\left.d_{6}\right): \delta \mathrm{ppm} 47.0$ (Ph- $\left.\mathrm{CH}_{2}\right), 64.2(\mathrm{C}-3), 66.9\left(\mathrm{CH}_{2} \mathrm{O}\right), 71.4(\mathrm{C}-2), 100.3$ (C-5), 103.2 (C$\left.4^{\prime}\right), \overline{106} .3$ (C-7), $115.6\left(\mathrm{C}-2^{\prime}, \mathrm{C}-6^{\prime}\right), 117.1(\mathrm{C}-8), 119.0(\mathrm{CN}), 126.4$ $\left(\mathrm{C}-4^{\prime \prime}\right), 127.1\left(\mathrm{C}-2^{\prime \prime}, \mathrm{C}-6^{\prime \prime}\right), 128.2\left(\mathrm{C}-3^{\prime \prime}, \mathrm{C}-5^{\prime \prime}\right), 133.6$ (C-8a), 134.2 (C-3', C-5'), 140.4 (C-6), $142.7\left(\mathrm{C}-1^{\prime \prime}\right), 143.9$ (C-4a), $161.6\left(\mathrm{C}-1^{\prime}\right)$; HRMS (ESI) $m / z$ calcd for $\mathrm{C}_{23} \mathrm{H}_{21} \mathrm{~N}_{2} \mathrm{O}_{3}[\mathrm{M}+\mathrm{H}]^{+} 373.1552$, found 373.1552; IR (KBr, $\left.v, \mathrm{~cm}^{-1}\right)$ : 2219, 1606, 1504, 1260, 1174, 1045, 830; HPLC: $98.1 \%, \mathrm{t}_{\mathrm{r}} 11.7 \mathrm{~min}$.

\subsubsection{4-((7-(Benzylamino)-2,3-dihydrobenzo[b][1,4]dioxin-2-yl) methoxy)benzonitrile ( $8 \boldsymbol{b})$}

Starting from $\mathbf{6 b}$ ( $1.10 \mathrm{~g}, 3.52 \mathrm{mmol}$ ) and benzaldehyde (334 mg, $3.15 \mathrm{mmol}$ ), compound $\mathbf{8 b}$ was prepared according to the procedure described above for the synthesis of 8a; yellow crystals, yield $539 \mathrm{mg}$ (41\% from 6b); mp $115-118{ }^{\circ} \mathrm{C} ;{ }^{1} \mathrm{H}$ NMR (400 MHz, DMSO$\left.d_{6}\right): \delta \mathrm{ppm} 4.00\left(\mathrm{dd}, J=11.5,7.2 \mathrm{~Hz}, 1 \mathrm{H}, 3-\mathrm{CH}_{2}\right), 4.18(\mathrm{~d}, J=5.6 \mathrm{~Hz}$, $\left.2 \mathrm{H}, \mathrm{PhCH}_{2}\right), 4.20-4.33\left(\mathrm{~m}, 3 \mathrm{H}, 3-\mathrm{CH}_{2}, \mathrm{CH}_{2} \mathrm{O}\right), 4.42-4.57(\mathrm{~m}, 1 \mathrm{H}$, $2-\mathrm{CH}), 5.93(\mathrm{t}, J=5.6 \mathrm{~Hz}, 1 \mathrm{H}, \mathrm{NH}), 6.07\left(\mathrm{~d}, J=2.6 \mathrm{~Hz}, 1 \mathrm{H}, \mathrm{Ar}-\mathrm{H}^{8}\right)$, $6.15\left(\mathrm{dd}, J=8.7,2.6 \mathrm{~Hz}, 1 \mathrm{H}, \mathrm{Ar}-\mathrm{H}^{6}\right), 6.62(\mathrm{~d}, J=8.7 \mathrm{~Hz}, 1 \mathrm{H}, \mathrm{Ar}-$ $\left.\mathrm{H}^{5}\right), 7.16\left(\mathrm{~d}, J=9.0 \mathrm{~Hz}, 2 \mathrm{H}, \mathrm{Ar}-\mathrm{H}^{2^{\prime}}, \mathrm{Ar}-\mathrm{H}^{6^{\prime}}\right), 7.19-7.25(\mathrm{~m}, 1 \mathrm{H}, \mathrm{Ph})$, $7.27-7.38(\mathrm{~m}, 4 \mathrm{H}, \mathrm{Ph}), 7.78\left(\mathrm{~d}, J=9.0 \mathrm{~Hz}, 2 \mathrm{H}, \mathrm{Ar}-\mathrm{H}^{3^{\prime}}, \mathrm{Ar}-\mathrm{H}^{5^{\prime}}\right) ;{ }^{13} \mathrm{C}$ NMR (101 MHz, DMSO- $\left.d_{6}\right): \delta$ ppm $47.0\left(\mathrm{Ph}-\mathrm{CH}_{2}\right) 64.2$ (C-3), 66.7 $\left(\mathrm{CH}_{2} \mathrm{O}\right), 71.4$ (C-2), 100.3 (C-8), $103.2\left(\mathrm{C}-8^{\prime \prime}\right), 106.3$ (C-6), 115.6 (C-2" C-6'), 117.1 (C-5), $119.0(\mathrm{CN}), 126.5\left(\mathrm{C}-4^{\prime \prime}\right), 127.1\left(\mathrm{C}-2^{\prime \prime}, \mathrm{C}-6^{\prime \prime}\right), 128.2$

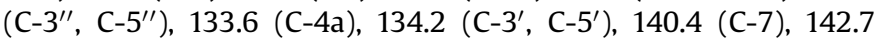
$\left(\mathrm{C}-1^{\prime \prime}\right), 143.9$ (C-8a), 161.6 (C-1'); HRMS (ESI) $m / z$ calcd for $\mathrm{C}_{23} \mathrm{H}_{21} \mathrm{~N}_{2} \mathrm{O}_{3}[\mathrm{M}+\mathrm{H}]^{+}$373. 1552, found 373.1546; IR $\left(\mathrm{KBr}, v, \mathrm{~cm}^{-1}\right)$ : 3387, 3050, 2220, 1508, 1262, 1174, 832; HPLC: 98.8\%, $\mathrm{t}_{\mathrm{r}} 11.7 \mathrm{~min}$.

\subsubsection{Ethyl 2-(benzyl(2-((4-cyanophenoxy)methyl)-2,3-}

dihydrobenzo[b][1,4]dioxin-6-yl)amino)-2-oxoacetate (9a)

Ethyl oxalyl chloride $(330 \mathrm{mg}, 2.42 \mathrm{mmol}$ ) was added to a solution of $8 \mathbf{a}(753 \mathrm{mg}, 2.02 \mathrm{mmol})$ and triethylamine $(245 \mathrm{mg}$, $2.42 \mathrm{mmol}$ ) in dichloromethane $(50 \mathrm{~mL})$ and the mixture stirred for $2 \mathrm{~h}$. The solvent was removed under reduced pressure, the residue dissolved in ethyl acetate $(50 \mathrm{~mL})$ and washed successively with a $10 \%$ citric acid solution $(3 \times 50 \mathrm{~mL})$, saturated $\mathrm{NaHCO}_{3}$ solution $(3 \times 50 \mathrm{~mL})$ and brine $(1 \times 50 \mathrm{~mL})$. The organic phase was dried over $\mathrm{Na}_{2} \mathrm{SO}_{4}$ and the solvent evaporated under reduced pressure.
The oily product was purified by column chromatography using dichloromethane as eluent to obtain $887 \mathrm{mg}$ (93\%) of 9a as pale yellow amorphous solid; ${ }^{1} \mathrm{H}$ NMR (400 MHz, DMSO- $d_{6}$ ): $\delta$ ppm 0.93 $\left(\mathrm{t}, J=7.1 \mathrm{~Hz}, 3 \mathrm{H}, \mathrm{CH}_{2} \underline{\mathrm{CH}}_{3}\right), 4.02\left(\mathrm{q}, J=7.1 \mathrm{~Hz}, 2 \mathrm{H}, \underline{\mathrm{CH}_{2}} \mathrm{CH}_{3}\right), 4.13$ (dd, $\left.J=11.6,7.4 \mathrm{~Hz}, 1 \mathrm{H}, 3-\overline{\mathrm{CH}}_{2}\right), 4.30\left(\mathrm{dd}, J=10.9,5.7 \mathrm{~Hz}, 1 \mathrm{H}, \mathrm{CH}_{2} \mathrm{O}\right), 4.37$ (dd, $\left.J=10.9,3.7 \mathrm{~Hz}, 1 \mathrm{H}, \mathrm{CH}_{2} \mathrm{O}\right), 4.44\left(\mathrm{dd}, J=11.6,2.4 \mathrm{~Hz}, 1 \mathrm{H}, 3-\mathrm{CH}_{2}\right.$ ), 4.49-4.58 (m, $1 \mathrm{H}, 2-\mathrm{CH}), 4.90\left(\mathrm{~s}, 2 \mathrm{H}, \mathrm{PhCH}_{2}\right), 6.62$ (dd, $J=8.6$, $\left.2.7 \mathrm{~Hz}, 1 \mathrm{H}, \mathrm{Ar}-\mathrm{H}^{7}\right), 6.78\left(\mathrm{~d}, J=2.7 \overline{\mathrm{Hz}}, 1 \mathrm{H}, \mathrm{Ar}-\mathrm{H}^{5}\right), 6.89$ $\left(\mathrm{d}, J=8.6 \mathrm{~Hz}, 1 \mathrm{H}, \mathrm{Ar}-\mathrm{H}^{8}\right), 7.15\left(\mathrm{~d}, J=9.0 \mathrm{~Hz}, 2 \mathrm{H}, \mathrm{Ar}-\mathrm{H}^{2^{\prime}}, \mathrm{Ar}-\mathrm{H}^{6^{\prime}}\right)$, 7.18-7.22 (m, 2H, Ph), 7.25-7.37 (m, 3H, Ph), 7.79 (d, $J=9.0 \mathrm{~Hz}$, $\left.2 \mathrm{H}, \mathrm{Ar}-\mathrm{H}^{3^{\prime}}, \mathrm{Ar}-\mathrm{H}^{5^{\prime}}\right) ;{ }^{13} \mathrm{C}$ NMR (101 MHz, DMSO-d $)$ : $\delta$ ppm 13.4 $\left(\mathrm{CH}_{2}-\mathrm{CH}_{3}\right), 50.8\left(\mathrm{Ph}-\mathrm{CH}_{2}\right), 61.3\left(\underline{\mathrm{CH}}_{2}-\mathrm{CH}_{3}\right), 64.4(\mathrm{C}-3), 66.6\left(\mathrm{CH}_{2} \mathrm{O}\right)$,

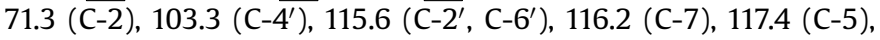
$119.0(\mathrm{CN}), 120.9(\mathrm{C}-8), 127.5\left(\mathrm{C}-4^{\prime \prime}\right), 128.0\left(\mathrm{C}-2^{\prime \prime}, \mathrm{C}-6^{\prime \prime}\right), 128.6\left(\mathrm{C}-3^{\prime \prime}\right.$,

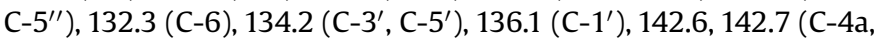
C-8a), 161.4, 161.5, 162.4 (CO-COO, CO-COO, C-1' $)$; HRMS (ESI) $m / z$ calcd for $\mathrm{C}_{27} \mathrm{H}_{25} \mathrm{~N}_{2} \mathrm{O}_{6}[\mathrm{M}+\mathrm{H}]^{+} 473.1713$, found 473.1711; IR (KBr, $v$, $\left.\mathrm{cm}^{-1}\right): 2224,1605,1507,1252,1175,1016,834$; HPLC: $100 \%, \mathrm{t}_{\mathrm{r}}$ $17.6 \mathrm{~min}$.

\subsubsection{Ethyl 2-(benzyl(3-((4-cyanophenoxy)methyl)-2,3-dihydrobenzo} [b][1,4]dioxin-7-yl)amino)-2-oxoacetate (9b)

Compound $\mathbf{9 b}$ was prepared from $\mathbf{8 b}(753 \mathrm{mg}, 2.02 \mathrm{mmol})$ and ethyl oxalyl chloride (330 $\mathrm{mg}, 2.42 \mathrm{mmol}$ ) according to the procedure described above for the synthesis of 9a; pale yellow solid, yield $811 \mathrm{mg}$ (85\%); ${ }^{1} \mathrm{H}$ NMR (400 MHz, DMSO- $\left.d_{6}\right): \delta$ ppm 0.93 $\left(\mathrm{t}, J=7.1 \mathrm{~Hz}, 3 \mathrm{H}, \mathrm{CH}_{2} \mathrm{CH}_{3}\right), 4.01\left(\mathrm{q}, J=7.1 \mathrm{~Hz}, 2 \mathrm{H}, \mathrm{CH}_{2} \mathrm{CH}_{3}\right), 4.11$ (dd, $\left.J=11.6,7.4 \mathrm{~Hz}, 1 \mathrm{H}, 3-\overline{\mathrm{CH}}_{2}\right), 4.30\left(\mathrm{dd}, J=11.1,5.8 \mathrm{~Hz}, 1 \mathrm{H}, \mathrm{CH}_{2} \mathrm{O}\right), 4.37$ (dd, $J=11.1,3.7 \mathrm{~Hz}, 1 \mathrm{H}, \mathrm{CH}_{2} \mathrm{O}$ ), 4.44 (dd, $J=11.6,2.4 \mathrm{~Hz}, 1 \mathrm{H}, 3-\mathrm{CH}_{2}$ ), $4.56-4.64(\mathrm{~m}, 1 \mathrm{H}, 2-\mathrm{CH}), 4.90\left(\mathrm{~s}, 2 \mathrm{H}, \mathrm{PhCH}_{2}\right), 6.62(\mathrm{dd}, J=8.6$, $\left.2.5 \mathrm{~Hz}, 1=, \mathrm{Ar}-\mathrm{H}^{6}\right), 6.78\left(\mathrm{~d}, J=2.5 \mathrm{~Hz}, 1 \mathrm{H}, \mathrm{Ar}-\mathrm{H}^{8}\right), 6.89$ $\left(\mathrm{d}, J=8.6 \mathrm{~Hz}, 1 \mathrm{H}, \mathrm{Ar}-\mathrm{H}^{5}\right), 7.15\left(\mathrm{~d}, J=9.0 \mathrm{~Hz}, 2 \mathrm{H}, \mathrm{Ar}-\mathrm{H}^{2^{\prime}}, \mathrm{Ar}-\mathrm{H}^{6^{\prime}}\right)$, 7.18-7.24 (m, 2H, Ph), 7.25-7.38 (m, 3H, Ph), $7.79(\mathrm{~d}, J=9.0 \mathrm{~Hz}$, $\left.2 \mathrm{H}, \mathrm{Ar}-\mathrm{H}^{3^{\prime}}, \mathrm{Ar}-\mathrm{H}^{5^{\prime}}\right) ;{ }^{13} \mathrm{C} \mathrm{NMR}$ (DMSO- $\left.d_{6}\right) \delta \mathrm{ppm}: 13.4\left(\mathrm{CH}_{2}-\mathrm{CH}_{3}\right)$, $50.8\left(\mathrm{Ph}-\mathrm{CH}_{2}\right), 61.3\left(\mathrm{CH}_{2}-\mathrm{CH}_{3}\right), 64.4(\mathrm{C}-3), 66.6\left(\mathrm{CH}_{2} \mathrm{O}\right), 71.3(\mathrm{C}-2)$, $103.3\left(\mathrm{C}-\overline{4^{\prime}}\right), 115.6\left(\overline{\mathrm{C}-2^{\prime}}, \mathrm{C}-6^{\prime}\right), 116.1(\mathrm{C}-6), 117.4(\mathrm{C}-5), 119.0(\mathrm{CN})$, 120.9 (C-8), $127.5\left(\mathrm{C}-4^{\prime \prime}\right), 128.0\left(\mathrm{C}-2^{\prime \prime}, \mathrm{C}-6^{\prime \prime}\right), 128.6\left(\mathrm{C}-3^{\prime \prime}, \mathrm{C}-5^{\prime \prime}\right)$, 132.3 (C-7), 134.2 (C-3', C-5'), 136.1 (C-1" ), 142.6, 142.7 (C-4a, C-8a), $161.4,161.5,162.4$ (CO-COO, CO-COO, C- $1^{\prime}$ ); HRMS (ESI) $m / z$ calcd for $\mathrm{C}_{27} \mathrm{H}_{25} \mathrm{~N}_{2} \mathrm{O}_{6}[\overline{\mathrm{M}}+\mathrm{H}]^{+} 473.1713$, found 473.1725; IR (KBr, $v$, $\mathrm{cm}^{-1}$ ): 2225, 1741, 1670, 1606, 1508, 1256, 1172, 1029, 835; HPLC: $100 \%, \mathrm{t}_{\mathrm{r}} 17.5 \mathrm{~min}$.

\subsubsection{Ethyl 2-(benzyl(2-((4-carbamimidoylphenoxy)methyl)-2,3- dihydrobenzo[b][1,4]dioxin-6-yl)amino)-2-oxoacetate trifluoroacetate (10a)}

Gaseous $\mathrm{HCl}$ was slowly introduced over $30 \mathrm{~min}$ into a solution of the nitrile $9 \mathbf{a}$ ( $482 \mathrm{mg}, 1.02 \mathrm{mmol}$ ) in anhydrous ethanol (30 mL). The reaction mixture was closed tightly and stirred for $24 \mathrm{~h}$ at room temperature. The solvent was evaporated in vacuo and the residue washed 3 times with anhydrous diethyl ether. The iminoether obtained was dissolved in anhydrous EtOH $(30 \mathrm{~mL})$, ammonium acetate $(236 \mathrm{mg}, 3.06 \mathrm{mmol}$ ) was added and the reaction mixture stirred for $24 \mathrm{~h}$ at room temperature. The solvent was evaporated in vacuo and the crude product purified by gradient reverse phase column chromatography using methanol/trifluoroacetic acid (40-80\% in $30 \mathrm{~min}$ ) as eluent. After evaporation of volatiles, white crystals were precipitated from trifluoroacetic acid, filtered off and dried to yield $307 \mathrm{mg}$ (50\%) of 10a as a white powder; mp 192-194 ${ }^{\circ} \mathrm{C} ;{ }^{1} \mathrm{H}$ NMR (400 MHz, DMSO- $\left.d_{6}\right): \delta$ ppm $0.93(\mathrm{t}, J=7.1 \mathrm{~Hz}$, $\left.3 \mathrm{H}, \mathrm{CH}_{2} \mathrm{CH}_{3}\right), 4.02\left(\mathrm{q}, J=7.1 \mathrm{~Hz}, 2 \mathrm{H}, \frac{\mathrm{CH}_{2}}{5} \mathrm{CH}_{3}\right), 4.14$ (dd, $J=11.7$, $7.4 \mathrm{~Hz}, 1 \mathrm{H}, 3-\mathrm{CH}_{2}$ ), 4.32 (dd, $J=11.0,5.7 \mathrm{~Hz}, 1 \mathrm{H}, \mathrm{CH}_{2} \mathrm{O}$ ), 4.39 (dd, $\left.J=10.9,3.6 \mathrm{~Hz}, 1 \mathrm{H}, \mathrm{CH}_{2} \mathrm{O}\right), 4.46\left(\mathrm{dd}, J=11.6,2.4 \mathrm{~Hz}, 1 \mathrm{H}, 3-\mathrm{CH}_{2}\right)$, 4.57-4.66 (m, 1H, 2-CH), $4.91\left(\mathrm{~s}, 2 \mathrm{H}, \mathrm{PhCH}_{2}\right), 6.63$ (dd, $J=8.6$, $\left.2.7 \mathrm{~Hz}, 1 \mathrm{H}, \mathrm{Ar}-\mathrm{H}^{8}\right), 6.79\left(\mathrm{~d}, J=2.7 \mathrm{~Hz}, 1 \mathrm{H}, \mathrm{Ar}-\mathrm{H}^{7}\right), 6.89$ 
$\left(\mathrm{d}, J=8.6 \mathrm{~Hz}, 1 \mathrm{H}, \mathrm{Ar}-\mathrm{H}^{5}\right), 7.16-7.25\left(\mathrm{~m}, 4 \mathrm{H}, \mathrm{Ph}, \mathrm{Ar}-\mathrm{H}^{2^{\prime}}, \mathrm{Ar}-\mathrm{H}^{6^{\prime}}\right)$, 7.27-7.37 (m, 3H, Ph), $7.83\left(\mathrm{~d}, J=9.0 \mathrm{~Hz}, 2 \mathrm{H}, \mathrm{Ar}-\mathrm{H}^{3^{\prime}}, \mathrm{Ar}-\mathrm{H}^{5^{\prime}}\right)$, $8.92\left(\mathrm{~s}, 2 \mathrm{H}, \mathrm{NH}_{2}\right), 9.16\left(\mathrm{~s}, 2 \mathrm{H}, \mathrm{NH}_{2}^{+}\right) ;{ }^{13} \mathrm{C}$ NMR (101 MHz, DMSO$\left.d_{6}\right): \delta$ ppm $13.4\left(\mathrm{CH}_{2}-\mathrm{CH}_{3}\right), 50.8\left(\mathrm{Ph}-\mathrm{CH}_{2}\right), 61.3\left(\mathrm{CH}_{2}-\mathrm{CH}_{3}\right), 64.4$ (C-3), $66.7\left(\mathrm{CH}_{2} \mathrm{O}\right), 71.3(\mathrm{C}-2), 114.8\left({\mathrm{C}-2^{\prime}}^{\prime}, \mathrm{C}-6^{\prime}\right), 116.2(\mathrm{C}-7), 117.1$ $\left(\mathrm{CF}_{3}-\mathrm{COOH},{ }^{1} J_{C, \mathrm{~F}}=299.3 \mathrm{~Hz}\right), 117.4(\mathrm{C}-5), 120.1\left(\mathrm{C}-4^{\prime}\right), 120.9(\mathrm{C}-8)$, $127.6\left(\mathrm{C}-4^{\prime \prime}\right), 128.0\left(\mathrm{C}-2^{\prime \prime}, \mathrm{C}-6^{\prime \prime}\right), 128.6\left(\mathrm{C}-3^{\prime \prime}, \mathrm{C}-5^{\prime \prime}\right), 130.2\left(\mathrm{C}-3^{\prime}, \mathrm{C}-5^{\prime}\right)$, 132.3 (C-6), 136.1 (C-1" $\left.{ }^{\prime \prime}\right), 142.6,142.7$ (C-4a, C-8a), $158.7\left(\mathrm{CF}_{3}-\right.$ $\left.\underline{\mathrm{COOH}},{ }^{2} J_{\mathrm{C}, \mathrm{F}}=31.5 \mathrm{~Hz}\right), 161.5,162.3,162.4,164.5(\underline{\mathrm{CO}}-\mathrm{COO}, \mathrm{CO}-$ COO, $\left.\mathrm{C}-1^{\prime}, \mathrm{C}(=\mathrm{NH}) \mathrm{NH}_{2}\right)$; HRMS (ESI) $\mathrm{m} / z$ calcd for $\mathrm{C}_{27} \mathrm{H}_{28} \mathrm{~N}_{3} \mathrm{O}_{6}$ $\overline{[\mathrm{M}}+\mathrm{H}]^{+} 490.1978$, found 490.1972; IR $\left(\mathrm{KBr}, v, \mathrm{~cm}^{-1}\right)$ : 3298, 3122, 1737, 1665, 1506, 1203, 843; HPLC: 100\%, t $\mathrm{r}_{\mathrm{r}} 12.4 \mathrm{~min}$.

\subsubsection{Ethyl 2-(benzyl(3-((4-carbamimidoylphenoxy)methyl)-2,3- dihydrobenzo[b][1,4]dioxin-7-yl)amino)-2-oxoacetate trifluoroacetate (10b)}

Compound 10b was prepared from nitrile $\mathbf{9 b}$ ( $482 \mathrm{mg}, 1.02 \mathrm{mmol}$ ) according to procedure described above for the synthesis of 10a; white powder, yield $335 \mathrm{mg}$ (54\%); mp 185-188 ${ }^{\circ} \mathrm{C}$; ${ }^{1} \mathrm{H}$ NMR (400 MHz, DMSO- $\left.d_{6}\right): \delta$ ppm $0.91\left(\mathrm{t}, J=7.1 \mathrm{~Hz}, 3 \mathrm{H}, \mathrm{CH}_{2} \underline{\mathrm{CH}}_{3}\right), 4.00$ (q, $\left.J=7.1 \mathrm{~Hz}, 2 \mathrm{H}, \mathrm{CH}_{2} \mathrm{CH}_{3}\right), 4.15\left(\mathrm{dd}, J=11.6,7.2 \mathrm{~Hz}, 1 \mathrm{H}, 3-\mathrm{CH}_{2}\right), 4.31$ (dd, $\left.J=11.1,6.1 \mathrm{~Hz}, 1 \mathrm{H}, \mathrm{CH}_{2} \mathrm{O}\right), 4.39$ (dd, $J=10.9,3.4 \mathrm{~Hz}, 1 \mathrm{H}, \mathrm{CH}_{2} \mathrm{O}$ ), 4.46 (dd, $\left.J=11.6,2.2 \mathrm{~Hz}, 1 \mathrm{H}, 3-\mathrm{CH}_{2}\right), 4.58-4.64(\mathrm{~m}, 1 \mathrm{H}, 2-\mathrm{CH}), 4.90(\mathrm{~s}, 2 \mathrm{H}$, $\left.\mathrm{PhCH}_{2}\right), 6.63\left(\mathrm{dd}, J=8.7,2.5 \mathrm{~Hz}, 1 \mathrm{H}, \mathrm{Ar}-\mathrm{H}^{6}\right), 6.80(\mathrm{~d}, J=2.5 \mathrm{~Hz}, 1 \mathrm{H}, \mathrm{Ar}-$ $\left.\mathrm{H}^{8}\right), 6.89\left(\mathrm{~d}, J=8.7 \mathrm{~Hz}, 1 \mathrm{H}, \mathrm{Ar}-\mathrm{H}^{5}\right), 7.15-7.38\left(\mathrm{~m}, 7 \mathrm{H}, \mathrm{Ph}, \mathrm{Ar}-\mathrm{H}^{2^{\prime}}, \mathrm{Ar}-\right.$ $\left.\mathrm{H}^{6^{\prime}}\right), 7.83\left(\mathrm{~d}, J=8.9 \mathrm{~Hz}, 2 \mathrm{H}, \mathrm{Ar}-\mathrm{H}^{3^{\prime}}, \mathrm{Ar}-\mathrm{H}^{5^{\prime}}\right), 8.91\left(\mathrm{~s}, 2 \mathrm{H}, \mathrm{NH}_{2}\right), 9.17(\mathrm{~s}$, $\left.2 \mathrm{H}, \mathrm{NH}_{2}^{+}\right) ;{ }^{13} \mathrm{C} \mathrm{NMR}\left(101 \mathrm{MHz}, \mathrm{DMSO}-d_{6}\right) \delta \mathrm{ppm}: 13.3\left(\mathrm{CH}_{2}-\mathrm{CH}_{3}\right), 50.8$ $\left(\mathrm{Ph}-\mathrm{CH}_{2}\right), 61.3\left(\underline{\mathrm{CH}_{2}}-\mathrm{CH}_{3}\right), 64.4(\mathrm{C}-3), 66.7\left(\mathrm{CH}_{2} \mathrm{O}\right), 71.3(\mathrm{C}-2), 114.8(\mathrm{C}-$ $\left.2^{\prime}, \mathrm{C}-6^{\prime}\right), 116.2(\mathrm{C}-6), 117.1\left(\mathrm{CF}_{3}-\mathrm{COOH},{ }^{1} \mathrm{~J}_{\mathrm{F}, \mathrm{F}}=299.2 \mathrm{~Hz}\right), 117.3(\mathrm{C}-5)$, $120.1\left(\mathrm{C}-4^{\prime}\right), 120.8(\mathrm{C}-8), 127.5\left(\mathrm{C}-4^{\prime \prime}\right), 127.9\left(\mathrm{C}-2^{\prime \prime}, \mathrm{C}-6^{\prime \prime}\right), 128.6\left(\mathrm{C}-3^{\prime \prime}, \mathrm{C}-\right.$ $\left.5^{\prime \prime}\right), 130.2\left(\mathrm{C}-3^{\prime}, \mathrm{C}-5^{\prime}\right), 132.5$ (C-7), $136.1\left(\mathrm{C}-1^{\prime \prime}\right), 142.5,142.8$ (C-4a, C$8 \mathrm{a}), 158.8\left(\mathrm{CF}_{3}-\mathrm{COOH},{ }^{2} J_{\mathrm{C}, \mathrm{F}}=31.5 \mathrm{~Hz}\right), 161.5,162.3,162.4,164.5$ ( $\mathrm{CO}-$ $\left.\mathrm{COO}, \mathrm{CO}-\mathrm{COO}, \overline{\mathrm{C}-1^{\prime}}, \mathrm{C}(=\mathrm{NH}) \mathrm{NH}_{2}\right)$; HRMS (ESI) $\mathrm{m} / \mathrm{z}$ calcd for $\mathrm{C}_{27} \mathrm{H}_{28} \mathrm{~N}_{3} \mathrm{O}_{6}[\mathrm{M}+\mathrm{H}]^{+}$490.1978, found 490.1970; IR $\left(\mathrm{KBr}, v, \mathrm{~cm}^{-1}\right)$ : 3345, 3109, 1742, 1670, 1500, 1197, 843; HPLC: 98.4\%, $\mathrm{t}_{\mathrm{r}} 12.7 \mathrm{~min}$.

\subsubsection{2-(Benzyl(2-((4-carbamimidoylphenoxy)methyl)-2,3-}

dihydrobenzo[b][1,4]dioxin-6-yl)amino)-2-oxoacetic acid (11a)

To a solution of ester 10a (150 $\mathrm{mg}, 0.25 \mathrm{mmol})$ in tetrahydrofuran $(3 \mathrm{~mL})$ and methanol $(1 \mathrm{~mL}), 1 \mathrm{M} \mathrm{LiOH}(1.50 \mathrm{~mL}, 1.50 \mathrm{mmol})$ was added and the mixture was stirred for $1 \mathrm{~h}$ at room temperature. The organic solvents were evaporated under vacuum and the resulting aqueous solution neutralized with $0.1 \%$ trifluoroacetic acid to precipitate the product which was filtered off and dried to obtain $72 \mathrm{mg}$ (63\%) of $\mathbf{1 1}$ as a white powder, mp $290-293{ }^{\circ} \mathrm{C} ;{ }^{1} \mathrm{H}$ NMR (400 MHz, DMSO- $\left.d_{6}\right): \delta \mathrm{ppm} 4.14(\mathrm{dd}, J=11.6,7.6 \mathrm{~Hz}, 1 \mathrm{H}$, $\left.3-\mathrm{CH}_{2}\right), 4.33$ (dd, $\left.J=11.0,5.6 \mathrm{~Hz}, 1 \mathrm{H}, \mathrm{CH}_{2} \mathrm{O}\right), 4.40$ (dd, $J=11.0,3.7 \mathrm{~Hz}$, $\left.1 \mathrm{H}, \mathrm{CH}_{2} \mathrm{O}\right), 4.46\left(\mathrm{dd}, J=11.6,2.3 \mathrm{~Hz}, 1 \mathrm{H}, 3-\mathrm{CH}_{2}\right), 4.57-4.66(\mathrm{~m}, 1 \mathrm{H}$, 2-CH), 4.88 (s, $\left.2 \mathrm{H}, \mathrm{PhCH}_{2}\right), 6.67$ (dd, $\left.J=8.6,2.5 \mathrm{~Hz}, 1 \mathrm{H}, \mathrm{Ar}-\mathrm{H}^{7}\right), 6.80$ $\left(\mathrm{d}, J=2.5 \mathrm{~Hz}, 1 \mathrm{H}, \mathrm{Ar}-\mathrm{H}^{5}\right), 6.89\left(\mathrm{~d}, J=8.6 \mathrm{~Hz}, 1 \mathrm{H}, \mathrm{Ar}-\mathrm{H}^{8}\right), 7.18-7.24$ $\left(\mathrm{m}, 4 \mathrm{H}, \mathrm{Ph}, \mathrm{Ar}-\mathrm{H}^{2^{\prime}}, \mathrm{Ar}-\mathrm{H}^{6^{\prime}}\right), 7.27-7.35(\mathrm{~m}, 3 \mathrm{H}, \mathrm{Ph}), 7.83(\mathrm{~d}$, $\left.J=8.9 \mathrm{~Hz}, 2 \mathrm{H}, \mathrm{Ar}-\mathrm{H}^{3^{\prime}}, \mathrm{Ar}-\mathrm{H}^{5^{\prime}}\right), 9.04\left(\mathrm{~s}, 2 \mathrm{H}, \mathrm{NH}_{2}\right), 9.17(\mathrm{~s}, 1 \mathrm{H}, \mathrm{NH})$; ${ }^{13} \mathrm{C}$ NMR (101 MHz, DMSO- $\left.d_{6}\right) \delta$ ppm: $49.6\left(\mathrm{Ph}^{-\mathrm{CH}_{2}}\right), 64.4(\mathrm{C}-3)$, $66.7\left(\mathrm{CH}_{2} \mathrm{O}\right), 71.0(\mathrm{C}-2), 114.7\left(\mathrm{C}-2^{\prime}, \mathrm{C}-6^{\prime}\right), 115.9(\overline{\mathrm{C}-7}), 116.6(\mathrm{C}-5)$, $120.2\left(\mathrm{C}-4^{\prime}\right), 120.6(\mathrm{C}-8), 127.0\left(\mathrm{C}-4^{\prime \prime}\right), 127.6\left(\mathrm{C}-2^{\prime \prime}, \mathrm{C}-6^{\prime \prime}\right), 128.3$ $\left(\mathrm{C}-3^{\prime \prime}, \mathrm{C}-5^{\prime \prime}\right), 129.8\left(\mathrm{C}-3^{\prime}, \mathrm{C}-5^{\prime}\right), 132.3$ (C-6), 137.7 (C-1"), 141.4, 142.0 (C-4a, C-8a), 162.0, 163.2, 164.0, 164.6 (CO-COO, CO-COO, $\left.\mathrm{C}-1^{\prime}, \quad \mathrm{C}(=\mathrm{NH}) \mathrm{NH}_{2}\right) ; \quad$ HRMS $(\mathrm{ESI}) \mathrm{m} / z$ calcd for $\mathrm{C}_{25} \mathrm{H}_{24} \overline{\mathrm{N}_{3} \mathrm{O}_{6}}$ $[\mathrm{M}+\mathrm{H}]^{+} 462.1665$, found 462.1677; IR $\left(\mathrm{KBr}, v, \mathrm{~cm}^{-1}\right)$ : 3368, 1609, 1503, 1255, 844; HPLC: $96.1 \%, \mathrm{t}_{\mathrm{r}} 9.5 \mathrm{~min}$.

\subsubsection{2-(Benzyl(3-((4-carbamimidoylphenoxy)methyl)-2,3-} dihydrobenzo[b][1,4]dioxin-7-yl)amino)-2-oxoacetic acid (11b)

Compound 11b was prepared from $10 \mathbf{b}(150 \mathrm{mg}, 0.25 \mathrm{mmol})$ according to procedure described above for the synthesis of 11a; white powder, yield $69 \mathrm{mg}(60 \%) ; \mathrm{mp} \mathrm{291-294}{ }^{\circ} \mathrm{C} ;{ }^{1} \mathrm{H}$ NMR $\left(400 \mathrm{MHz}, \mathrm{DMSO}-d_{6}\right): \delta \mathrm{ppm} 4.13$ (dd, $J=11.6,7.9 \mathrm{~Hz}, 1 \mathrm{H}, 3-\mathrm{CH}_{2}$ ), $4.34\left(\mathrm{dd}, J=10.9,5.6 \mathrm{~Hz}, 1 \mathrm{H}, \mathrm{CH}_{2} \mathrm{O}\right), 4.40(\mathrm{dd}, J=10.9,3.6 \mathrm{~Hz}, 1 \mathrm{H}$, $\mathrm{CH}_{2} \mathrm{O}$ ), 4.48 (dd, $\left.J=11.6,2.2 \mathrm{~Hz}, 1 \mathrm{H}, 3-\mathrm{CH}_{2}\right), 4.55-4.65(\mathrm{~m}, 1 \mathrm{H}$, 2-CH), $4.88\left(\mathrm{~s}, 2 \mathrm{H}, \mathrm{PhCH}_{2}\right), 6.68\left(\mathrm{dd}, J=8.6,2.5 \mathrm{~Hz}, 1 \mathrm{H}, \mathrm{Ar}-\mathrm{H}^{6}\right), 6.80$ $\left(\mathrm{d}, J=2.5 \mathrm{~Hz}, 1 \mathrm{H}, \mathrm{Ar}-\mathrm{H}^{8}\right), 6.89\left(\mathrm{~d}, J=8.6 \mathrm{~Hz}, 1 \mathrm{H}, \mathrm{Ar}-\mathrm{H}^{5}\right), 7.18-7.37$ $\left(\mathrm{m}, 7 \mathrm{H}, \mathrm{Ph}, \mathrm{Ar}-\mathrm{H}^{2^{\prime}}, \mathrm{Ar}-\mathrm{H}^{6^{\prime}}\right), 7.83\left(\mathrm{~d}, J=8.9 \mathrm{~Hz}, 2 \mathrm{H}, \mathrm{Ar}-\mathrm{H}^{3^{\prime}}, \mathrm{Ar}-\mathrm{H}^{5^{\prime}}\right)$, $8.91\left(\mathrm{~s}, 2 \mathrm{H}, \mathrm{NH}_{2}\right), 9.17(\mathrm{~s}, 1 \mathrm{H}, \mathrm{NH}) ;{ }^{13} \mathrm{C}$ NMR (101 MHz, DMSO-d $\left.d_{6}\right)$ $\delta$ ppm: $50.6\left(\mathrm{Ph}_{-} \mathrm{CH}_{2}\right), 64.4(\mathrm{C}-3), 66.8\left(\mathrm{CH}_{2} \mathrm{O}\right), 71.4(\mathrm{C}-2), 114.9\left(\mathrm{C}-2^{\prime}\right.$, C-6'), 116.1 (C-8), 117.3 (C-6), $120.1\left(\mathrm{C}-4^{\prime}\right), 120.7$ (C-5), $127.4\left(\mathrm{C}-4^{\prime \prime}\right)$, $127.8\left(\mathrm{C}-2^{\prime \prime}, \mathrm{C}-6^{\prime \prime}\right), 128.5\left(\mathrm{C}-3^{\prime \prime}, \mathrm{C}-5^{\prime \prime}\right), 130.2\left(\mathrm{C}-3^{\prime}, \mathrm{C}-5^{\prime}\right), 133.0(\mathrm{C}-7)$, $136.3\left(\mathrm{C}-1^{\prime \prime}\right), 142.5,142.6$ (C-4a, C-8a), 162.3, 163.1, 164.2, 164.5 (CO-COO, CO-COO, $\left.\mathrm{C}-1^{\prime}, \mathrm{C}(=\mathrm{NH}) \mathrm{NH}_{2}\right)$; HRMS (ESI) $\mathrm{m} / \mathrm{z}$ calcd for $\overline{\mathrm{C}_{25}} \mathrm{H}_{24} \mathrm{~N}_{3} \mathrm{O}_{6}[\mathrm{M}+\mathrm{H}]^{+} 462.1665$, found 462.1674; IR $\left(\mathrm{KBr}, v, \mathrm{~cm}^{-1}\right)$ : 3309, 1609, 1492, 1262, 839; HPLC: 96.2\%, $\mathrm{t}_{\mathrm{r}} 9.7 \mathrm{~min}$.

\subsubsection{1. (2,4-Dimethyl-7-nitro-3,4-dihydro-2H-benzo[b][1,4]oxazin- 2-yl)methyl acetate (13)}

Alcohol 12 [22] (2.00 g, $8.4 \mathrm{mmol})$ was dissolved in acetic anhydride $(50 \mathrm{~mL})$ and heated at $100{ }^{\circ} \mathrm{C}$ for $5 \mathrm{~h}$. The excess acetic anhydride was removed in vacuo to yield $2.02 \mathrm{~g}$ (86\%) of $\mathbf{1 3}$ as brown oil; ${ }^{1} \mathrm{H}$ NMR (400 MHz, DMSO-d $\left.d_{6}\right) \delta \mathrm{ppm} 1.36\left(\mathrm{~s}, 3 \mathrm{H}, 2-\mathrm{CH}_{3}\right)$, $2.09\left(\mathrm{~s}, 3 \mathrm{H}, \mathrm{COCH}_{3}\right), 2.99\left(\mathrm{~s}, 3 \mathrm{H}, \mathrm{NCH}_{3}\right), 3.16(\mathrm{~d}, J=12.1 \mathrm{~Hz}, 1 \mathrm{H}, 3-\mathrm{H})$, $3.32(\mathrm{~d}, J=12.1 \mathrm{~Hz}, 1 \mathrm{H}, 3-\mathrm{H}), 4.15\left(\mathrm{~d}, J=11.6 \mathrm{~Hz}, 1 \mathrm{H}, \mathrm{CH}_{2} \mathrm{O}\right), 4.20$ (d, $\left.J=11.6 \mathrm{~Hz}, 1 \mathrm{H}, \mathrm{CH}_{2} \mathrm{O}\right), 6.92\left(\mathrm{~d}, J=8.8 \mathrm{~Hz}, 1 \mathrm{H}, \mathrm{Ar}-\mathrm{H}^{5}\right), 7.51(\mathrm{~d}$, $\left.J=2.6 \mathrm{~Hz}, 1 \mathrm{H}, \mathrm{Ar}-\mathrm{H}^{8}\right), 7.58\left(\mathrm{dd}, J=8.8,2.6 \mathrm{~Hz}, 1 \mathrm{H}, \mathrm{Ar}-\mathrm{H}^{6}\right) ;{ }^{13} \mathrm{C} \mathrm{NMR}$ $\left(101 \mathrm{MHz}, \mathrm{DMSO}-d_{6}\right) \delta \mathrm{ppm} 20.5\left(\mathrm{COCH}_{3}\right), 20.6\left(2-\mathrm{CH}_{3}\right), 38.0$ $\left(\mathrm{NCH}_{3}\right), 52.8(\mathrm{C}-3), 66.0\left(\mathrm{CH}_{2} \mathrm{O}\right), 75.4(\mathrm{C}-2), 106.2(\mathrm{C}-8), 114.1$ (C-6), 115.7 (C-5), 135.4 (C-7), 141.5 (C-8a), 148.2 (C-4a), 170.0 (CO); HRMS (ESI) $m / z$ calcd for $\mathrm{C}_{13} \mathrm{H}_{17} \mathrm{~N}_{2} \mathrm{O}_{5}[\mathrm{M}+\mathrm{H}]^{+}$281.1137, found 281.1132; HPLC: 97.0\%, $\mathrm{t}_{\mathrm{r}} 14.3$ min; Anal. $\left(\mathrm{C}_{13} \mathrm{H}_{16} \mathrm{~N}_{2} \mathrm{O}_{5}\right)$ : C, $\mathrm{H}, \mathrm{N}$.

\subsubsection{2. (7-(Benzylamino)-2,4-dimethyl-3,4-dihydro-2H-benzo[b] [1,4]oxazin-2-yl)methanol (15a)}

Prepared from compound 13 (1.66 g, $5.93 \mathrm{mmol}$ ) and benzaldehyde (548 mg, $5.16 \mathrm{mmol}$ ) following the procedure for the synthesis of compound 8a; yellow oil, yield $1.23 \mathrm{~g}(70 \%$ from 13$) ;{ }^{1} \mathrm{H}$ NMR (400 MHz, DMSO-d $d_{6} \delta$ ppm $1.16\left(\mathrm{~s}, 3 \mathrm{H}, 2-\mathrm{CH}_{3}\right), 2.74(\mathrm{~s}, 3 \mathrm{H}$, $\left.\mathrm{NCH}_{3}\right), 2.81(\mathrm{~d}, J=11.4 \mathrm{~Hz}, 1 \mathrm{H}, 3-\mathrm{H}), 3.03(\mathrm{~d}, J=11.4 \mathrm{~Hz}, 1 \mathrm{H}, 3-\mathrm{H})$, 3.27 (dd, $J=10.7,5.8 \mathrm{~Hz}, 1 \mathrm{H}, \mathrm{CH}_{2} \mathrm{O}$ ), 3.35-3.43 (m, overlapped with $\left.\mathrm{H}_{2} \mathrm{O}, 1 \mathrm{H}, \mathrm{CH}_{2} \mathrm{O}\right), 4.18$ (d, $\left.6.13 \mathrm{~Hz}, \mathrm{~N}-\mathrm{CH}_{2}\right), 4.90(\mathrm{t}, J=5.3 \mathrm{~Hz}, 1 \mathrm{H}, \mathrm{OH})$, $5.56(\mathrm{t}, J=5.6 \mathrm{~Hz}, 1 \mathrm{H}, \mathrm{NH}), 5.83\left(\mathrm{dd}, J=8.4,2.3 \mathrm{~Hz}, 1 \mathrm{H}, \mathrm{Ar}-\mathrm{H}^{6}\right), 6.03$ $\left(\mathrm{d}, J=2.3 \mathrm{~Hz}, 1 \mathrm{H}, \mathrm{Ar}-\mathrm{H}^{8}\right), 6.37\left(\mathrm{~d}, J=8.4 \mathrm{~Hz}, 1 \mathrm{H}, \mathrm{Ar}-\mathrm{H}^{5}\right), 7.17-7.40$ $(\mathrm{m}, 5 \mathrm{H}, \mathrm{Ph}) ;{ }^{13} \mathrm{C}$ NMR $\left(101 \mathrm{MHz}\right.$, DMSO- $\left.d_{6}\right) \delta \mathrm{ppm} 20.9\left(2-\mathrm{CH}_{3}\right), 38.3$ $\left(\mathrm{NCH}_{3}\right), 47.5\left(\mathrm{NCH}_{2}\right), 54.2(\mathrm{C}-3), 65.0\left(\mathrm{CH}_{2} \mathrm{O}\right), 74.5(\mathrm{C}-2), 97.6(\mathrm{C}-6)$, 101.8 (C-8), 115.5 (C-5), 126.4 (C-4'), 127.2 (C-2', C-6'), 128.1 (C-3', C-5') 134.4, 135.5 (C-4a, C-8a), 140.9, 143.1 (C-7, C-1'); HRMS (ESI) $m / z$ calcd for $\mathrm{C}_{18} \mathrm{H}_{23} \mathrm{~N}_{2} \mathrm{O}_{2}[\mathrm{M}+\mathrm{H}]^{+} 299.1760$, found 299.1755; HPLC: 97.3\%, $\mathrm{t}_{\mathrm{r}} 6.5 \mathrm{~min}$; Anal. $\left(\mathrm{C}_{18} \mathrm{H}_{22} \mathrm{~N}_{2} \mathrm{O}_{2} \times 1 / 4 \mathrm{H}_{2} \mathrm{O}\right): \mathrm{C}, \mathrm{H}, \mathrm{N}$.

\subsubsection{3. (7-((3,5-Difluorobenzyl)amino)-2,4-dimethyl-3,4-dihydro-} 2H-benzo[b][1,4]oxazin-2-yl)methanol (15b)

Prepared from compound $13(1.71 \mathrm{~g}, 6.10 \mathrm{mmol})$ and 3,5difluorobenzaldehyde $(693 \mathrm{mg}, 4.88 \mathrm{mmol})$ following the procedure for the synthesis of compound 8a; yellow oil, yield $1.19 \mathrm{~g}(58 \%$ from 13); ${ }^{1} \mathrm{H}$ NMR (400 MHz, DMSO-d 6 ) $\delta$ ppm $1.16\left(\mathrm{~s}, 3 \mathrm{H}, 2-\mathrm{CH}_{3}\right)$, $2.75\left(\mathrm{~s}, 3 \mathrm{H}, \mathrm{NCH}_{3}\right), 2.82(\mathrm{~d}, J=11.36 \mathrm{~Hz}, 1 \mathrm{H}, 3-\mathrm{H}), 3.04(\mathrm{~d}$, $J=11.36 \mathrm{~Hz}, 1 \mathrm{H}, 3-\mathrm{H}), 3.28\left(\mathrm{dd}, J=10.59,5.16 \mathrm{~Hz}, 1 \mathrm{H}, \mathrm{CH}_{2} \mathrm{O}\right), 3.42-$ $3.36\left(\mathrm{~m}, 1 \mathrm{H}, \mathrm{CH}_{2} \mathrm{O}\right), 4.22\left(\mathrm{~d}, 6.13 \mathrm{~Hz}, \mathrm{~N}-\mathrm{CH}_{2}\right), 4.91(t, J=5.3 \mathrm{~Hz}, 1 \mathrm{H}$, $\mathrm{OH}), 5.48(\mathrm{t}, J=5.6 \mathrm{~Hz}, 1 \mathrm{H}, \mathrm{NH}), 5.79(\mathrm{dd}, J=8.38,1.79 \mathrm{~Hz}, 1 \mathrm{H}, \mathrm{Ar}-$ $\left.\mathrm{H}^{6}\right), 6.01\left(\mathrm{~d}, J=1.68 \mathrm{~Hz}, 1 \mathrm{H} \mathrm{Ar}-\mathrm{H}^{8}\right), 6.38\left(\mathrm{~d}, J=8.40 \mathrm{~Hz}, 1 \mathrm{H}, \mathrm{Ar}-\mathrm{H}^{5}\right)$, 6.99-7.12 (m, 3H, 3Ar-H); ${ }^{13} \mathrm{C}$ NMR (101 MHz, DMSO- $\left.d_{6}\right) \delta \mathrm{ppm}$ $20.9\left(2-\mathrm{CH}_{3}\right), 38.2\left(\mathrm{NCH}_{3}\right), 46.6\left(\mathrm{CH}_{2} \mathrm{~N}\right), 54.2(\mathrm{C}-3), 64.9\left(\mathrm{CH}_{2} \mathrm{O}\right), 74.5$ (C-2), 97.7 (C-6), 101.7 (C-8), 101.7 (t, $\left.{ }^{2} J_{C-F}=25.9 \mathrm{~Hz}, \mathrm{C}-4^{\prime}\right), 109.5$ $\left(\mathrm{dd},{ }^{2} J_{\mathrm{C}-\mathrm{F}}=24.7 \mathrm{~Hz},{ }^{4} J_{\mathrm{C}-\mathrm{F}}=6.3 \mathrm{~Hz}, \mathrm{C}-2^{\prime}, \mathrm{C}-6^{\prime}\right), 115.6(\mathrm{C}-5), 134.7$, 
135.6, 142.4 (C-7, C-4a, C-8a), 146.6 (t, $\left.{ }^{3} \mathrm{~J}_{\mathrm{C}-\mathrm{F}}=8.2 \mathrm{~Hz}, \mathrm{C}-1^{\prime}\right), 162.4$ (dd, ${ }^{1} J_{\mathrm{C}-\mathrm{F}}=245.8 \mathrm{~Hz},{ }^{3} J_{\mathrm{C}-\mathrm{F}}=13.1 \mathrm{~Hz}, \mathrm{C}-3^{\prime}, \mathrm{C}-5^{\prime}$ ); HRMS (ESI) $\mathrm{m} / \mathrm{z}$ calcd for $\mathrm{C}_{18} \mathrm{H}_{21} \mathrm{~N}_{2} \mathrm{O}_{2} \mathrm{~F}_{2}[\mathrm{M}+\mathrm{H}]^{+} 335.1571$, found 335.1558; HPLC: $96.9 \%, \mathrm{t}_{\mathrm{r}} 7.8$ min; Anal. $\left(\mathrm{C}_{18} \mathrm{H}_{20} \mathrm{~N}_{2} \mathrm{O}_{2} \mathrm{~F}_{2}\right): \mathrm{C}, \mathrm{H}, \mathrm{N}$.

4.1.14. Ethyl 2-(benzyl(2-(hydroxymethyl)-2,4-dimethyl-3,4dihydro-2H-benzo[b][1,4]oxazin-7-yl)amino)-2-oxoacetate (16a)

Compound 16a was prepared from 15a ( $483 \mathrm{mg}, 1.62 \mathrm{mmol}$ ) and ethyl oxalyl chloride ( $221 \mathrm{mg}, 1.62 \mathrm{mmol}$ ) according to the procedure described above for the synthesis of 9a; yellow oil, yield $458 \mathrm{mg}$ (71\%); ${ }^{1} \mathrm{H}$ NMR (400 MHz, DMSO- $\left.d_{6}\right) \delta \mathrm{ppm} 0.89(\mathrm{t}$, $\left.J=7.1 \mathrm{~Hz}, 3 \mathrm{H}, \mathrm{CH}_{2} \mathrm{CH}_{3}\right), 1.17\left(\mathrm{~s}, 3 \mathrm{H}, 2-\mathrm{CH}_{3}\right), 2.82\left(\mathrm{~s}, 3 \mathrm{H}, \mathrm{NCH}_{3}\right), 2.89$ (d, $J=11.7 \mathrm{~Hz}, 1 \mathrm{H}, 3-\mathrm{H}), 3.11$ (d, $J=11.7 \mathrm{~Hz}, 1 \mathrm{H}, 3-\mathrm{H}), 3.29$ (dd, $J=10.8,5.9 \mathrm{~Hz}, 1 \mathrm{H}, \mathrm{CH}_{2} \mathrm{O}$ ), 3.33-3.43 (m, overlapped with $\mathrm{H}_{2} \mathrm{O}, 1 \mathrm{H}$, $\mathrm{CH}_{2} \mathrm{O}$ ), 3.97 (q, $\left.J=7.1 \mathrm{~Hz}, 1 \mathrm{H}, \mathrm{CH}_{2} \mathrm{CH}_{3}\right), 4.85\left(\mathrm{~s}, 2 \mathrm{H}, \mathrm{CH}_{2} \mathrm{~N}\right), 5.04(\mathrm{t}$, $J=5.7 \mathrm{~Hz}, 1 \mathrm{H}, \mathrm{OH}), 6.48\left(\mathrm{~d}, J=2.2 \mathrm{~Hz}, 1 \mathrm{H}, \mathrm{Ar}-\mathrm{H}^{8}\right), 6.51(\mathrm{dd}, J=8.5$, $\left.2.2 \mathrm{~Hz}, 1 \mathrm{H}, \mathrm{Ar}-\mathrm{H}^{6}\right), 6.60\left(\mathrm{~d}, J=8.5 \mathrm{~Hz}, 1 \mathrm{H}, \mathrm{Ar}-\mathrm{H}^{5}\right), 7.19(\mathrm{~d}, J=7.4 \mathrm{~Hz}$, $\left.2 \mathrm{H}, \mathrm{Ar}-\mathrm{H}^{2^{\prime}}, \mathrm{Ar}-\mathrm{H}^{6^{\prime}}\right), 7.24-7.30\left(\mathrm{~m}, 1 \mathrm{H}, \mathrm{Ar}-\mathrm{H}^{4^{\prime}}\right), 7.33(\mathrm{~m}, J=7.4 \mathrm{~Hz}$, $\left.2 \mathrm{H}, \mathrm{Ar}-\mathrm{H}^{3^{\prime}}, \mathrm{Ar}-\mathrm{H}^{5^{\prime}}\right) ;{ }^{13} \mathrm{C}$ NMR (101 MHz, DMSO-d 6 ) $\delta$ ppm 13.4 $\left(\mathrm{CH}_{2} \mathrm{CH}_{3}\right), 20.7\left(2-\mathrm{CH}_{3}\right), 38.1\left(\mathrm{NCH}_{3}\right), 50.9\left(\mathrm{CH}_{2} \mathrm{~N}\right), 53.2(\mathrm{C}-3), 61.0$ $\left(\mathrm{CH}_{2} \overline{\mathrm{CH}}_{3}\right), 64.7\left(\mathrm{CH}_{2} \mathrm{O}\right), 75.8(\mathrm{C}-2), 111.3(\mathrm{C}-5), 114.5$ (C-8), 120.0 (C-6), $127.4\left(\mathrm{C}-4^{\prime}\right), 127.8\left(\mathrm{C}-2^{\prime}, \mathrm{C}-6^{\prime}\right), 128.5\left(\mathrm{C}-3^{\prime}, \mathrm{C}-5^{\prime}\right), 128.7$ (C-7), 135.5, 136.4, 142.5 (C-1', C-4a, C-8a), 161.8, 162.7 (CO-COO, COCOO); HRMS (ESI) $m / z$ calcd for $\mathrm{C}_{22} \mathrm{H}_{27} \mathrm{~N}_{2} \mathrm{O}_{5}[\mathrm{M}+\mathrm{H}]^{+}$ 399.1920, found 399.1916; HPLC: 96.8\%, $\mathrm{t}_{\mathrm{r}} 14.5 \mathrm{~min}$; Anal. $\left(\mathrm{C}_{22} \mathrm{H}_{26} \mathrm{~N}_{2} \mathrm{O}_{5}\right): \mathrm{C}, \mathrm{H}, \mathrm{N}$.

4.1.15. Ethyl 2-((3,5-difluorobenzyl)(2-(hydroxymethyl)-2,4dimethyl-3,4-dihydro-2H-benzo[b][1,4]oxazin-7-yl)amino)-2oxoacetate (16b)

Compound 16b was prepared from $15 \mathbf{b}(592 \mathrm{mg}, 1.77 \mathrm{mmol})$ and ethyl oxalyl chloride ( $242 \mathrm{mg}, 1.77 \mathrm{mmol}$ ) according to the procedure described above for the synthesis of 9a; yellow oil, yield $529 \mathrm{mg}$ (69\%); ${ }^{1} \mathrm{H}$ NMR (400 MHz, DMSO- $\left.d_{6}\right) \delta \mathrm{ppm} 0.90(\mathrm{t}$, $\left.J=7.1 \mathrm{~Hz}, 3 \mathrm{H}, \mathrm{CH}_{2} \underline{\mathrm{CH}}_{3}\right), 1.18\left(\mathrm{~s}, 3 \mathrm{H}, 2-\mathrm{CH}_{3}\right), 2.83\left(\mathrm{~s}, 3 \mathrm{H}, \mathrm{NCH}_{3}\right), 2.90$ (d, $J=11.7 \mathrm{~Hz}, 1 \mathrm{H}, 3-\mathrm{H}$ ), 3.12 (d, $J=11.7 \mathrm{~Hz}, 1 \mathrm{H}, 3-\mathrm{H}), 3.30$ (dd, $J=10.8,4.1 \mathrm{~Hz}, 1 \mathrm{H}, \mathrm{CH}_{2} \mathrm{O}$ ), 3.40 (dd, $J=10.8,4.1 \mathrm{~Hz}, 1 \mathrm{H}, \mathrm{CH}_{2} \mathrm{O}$ ), 3.99 $\left(\mathrm{d}, J=7.1 \mathrm{~Hz}, 1 \mathrm{H}, \mathrm{CH}_{2} \mathrm{CH}_{3}\right), 4.88\left(\mathrm{~s}, 2 \mathrm{H}, \mathrm{CH}_{2} \mathrm{~N}\right), 5.04(\mathrm{t}, J=5.7 \mathrm{~Hz}, 1 \mathrm{H}$, $\mathrm{OH}), 6.52-6.57\left(\mathrm{~m}, 2 \mathrm{H}, \mathrm{Ar}-\mathrm{H}^{8}, \mathrm{Ar}-\mathrm{H}^{6}\right), 6.63(\mathrm{~d}, J=8.3 \mathrm{~Hz}, 1 \mathrm{H}, \mathrm{Ar}-$ $\left.\mathrm{H}^{5}\right), 6.87-6.94\left(\mathrm{~m}, 2 \mathrm{H}, \mathrm{Ar}-\mathrm{H}^{2^{\prime}}, \mathrm{Ar}-\mathrm{H}^{6^{\prime}}\right), 7.13-7.22\left(\mathrm{~m}, 1 \mathrm{H}, \mathrm{Ar}-\mathrm{H}^{4^{\prime}}\right)$; ${ }^{13} \mathrm{C}$ NMR (101 MHz, DMSO- $\left.d_{6}\right) \delta$ ppm $13.4\left(\mathrm{CH}_{2} \mathrm{CH}_{3}\right), 20.7\left(2-\mathrm{CH}_{3}\right)$, $38.1\left(\mathrm{NCH}_{3}\right), 50.2\left(\mathrm{CH}_{2} \mathrm{~N}\right), 53.2(\mathrm{C}-3), 61.2\left(\mathrm{CH}_{2} \overline{\mathrm{CH}}_{3}\right), 64.7\left(\mathrm{CH}_{2} \mathrm{O}\right)$, $75.8(\mathrm{C}-2), 103.0\left(\mathrm{t},{ }^{2} J_{\mathrm{C}-\mathrm{F}}=25.8 \mathrm{~Hz}, \mathrm{C}-4^{\prime}\right), 110.9\left(\mathrm{dd},{ }^{2} J_{\mathrm{C}-\mathrm{F}}=18.6 \mathrm{~Hz}\right.$, $\left.{ }^{4} J_{\mathrm{C}-\mathrm{F}}=6.8 \mathrm{~Hz}, \mathrm{C}-2^{\prime}, \mathrm{C}^{\prime} 6^{\prime}\right), 111.4(\mathrm{C}-5), 114.2(\mathrm{C}-8), 119.8$ (C-6), 128.4 (C-7), 135.7 (C-8a), $141.1\left(\mathrm{t},{ }^{3} \mathrm{~J}_{\mathrm{C}-\mathrm{F}}=9.1 \mathrm{~Hz}, \mathrm{C}-1^{\prime}\right), 142.6(\mathrm{C}-4 \mathrm{a}), 161.9$ (CO-COO), 162.3 (dd, ${ }^{1} J_{\mathrm{C}-\mathrm{F}}=246.7 \mathrm{~Hz},{ }^{3} J_{\mathrm{C}-\mathrm{F}}=13.2 \mathrm{~Hz}, \mathrm{C}-3^{\prime}, \mathrm{C}-5^{\prime}$ ), 162.5 (CO-COO); HRMS (ESI) $m / z$ calcd for $\mathrm{C}_{22} \mathrm{H}_{25} \mathrm{~N}_{2} \mathrm{O}_{5} \mathrm{~F}_{2}[\mathrm{M}+\mathrm{H}]^{+}$ 435.1732, found 435.1738; HPLC: 97.6\%, $\mathrm{t}_{\mathrm{r}} 15.6 \mathrm{~min}$; Anal. $\left(\mathrm{C}_{22} \mathrm{H}_{24} \mathrm{~N}_{2} \mathrm{O}_{5} \mathrm{~F}_{2}\right): \mathrm{C}, \mathrm{H}, \mathrm{N}$.

\subsubsection{2-(Benzyl(2-(hydroxymethyl)-2,4-dimethyl-3,4-dihydro-2H- benzo[b][1,4]oxazin-7-yl)amino)-2-oxoacetic acid (17a)}

Compound 17a was prepared by hydrolysis of ester $16 a(398 \mathrm{mg}$, $1 \mathrm{mmol})$ with $1 \mathrm{M} \mathrm{LiOH}(6 \mathrm{~mL})$ in a mixture of tetrahydrofuran and methanol according to the procedure for the synthesis of compound 11a to obtain $296 \mathrm{mg}$ (78\%) of 17a as brown oil; ${ }^{1} \mathrm{H}$ NMR (400 MHz, DMSO- $\left.d_{6}\right) \delta$ ppm $1.18\left(\mathrm{~s}, 3 \mathrm{H}, 2-\mathrm{CH}_{3}\right), 2.82\left(\mathrm{~s}, 3 \mathrm{H}, \mathrm{NCH}_{3}\right.$ ), 2.89 (d, $J=11.6 \mathrm{~Hz}, 1 \mathrm{H}, 3-\mathrm{H}), 3.11$ (d, $J=11.6 \mathrm{~Hz}, 1 \mathrm{H}, 3-\mathrm{H}), 3.30$ (d, $J=10.8 \mathrm{~Hz}, 1 \mathrm{H}, \mathrm{CH}_{2} \mathrm{O}$ ), 3.40 (d, $\left.J=10.8 \mathrm{~Hz}, 1 \mathrm{H}, \mathrm{CH}_{2} \mathrm{O}\right), 4.83$ (s, $2 \mathrm{H}$, $\mathrm{CH}_{2} \mathrm{~N}$ ), 5.04 (bs, $\left.1 \mathrm{H}, \mathrm{OH}\right), 6.48-6.64\left(\mathrm{~m}, 3 \mathrm{H}, \mathrm{Ar}-\mathrm{H}^{8}, \mathrm{Ar}-\mathrm{H}^{6}, \mathrm{Ar}-\mathrm{H}^{5}\right)$, $7.20\left(\mathrm{~d}, J=7.5 \mathrm{~Hz}, 2 \mathrm{H}, \mathrm{Ar}-\mathrm{H}^{2^{\prime}}, \mathrm{Ar}-\mathrm{H}^{6^{\prime}}\right), 7.23-7.29\left(\mathrm{~m}, 1 \mathrm{H}, \mathrm{Ar}-\mathrm{H}^{4^{\prime}}\right)$, $7.32\left(\mathrm{~d}, J=7.5 \mathrm{~Hz}, 2 \mathrm{H}, \mathrm{Ar}-\mathrm{H}^{3^{\prime}}, \mathrm{Ar}-\mathrm{H}^{5^{\prime}}\right) ;{ }^{13} \mathrm{C}$ NMR (101 MHz, DMSO$\left.d_{6}\right) \delta \mathrm{ppm} 20.8\left(2-\mathrm{CH}_{3}\right), 38.1\left(\mathrm{NCH}_{3}\right), 50.8\left(\mathrm{CH}_{2} \mathrm{~N}\right), 53.2(\mathrm{C}-3), 64.8$ $\left(\mathrm{CH}_{2} \mathrm{O}\right), 75.9$ (C-2), 111.4 (C-5), 114.3 (C-8), 119.9 (C-6), $127.3\left(\mathrm{C}-4^{\prime}\right)$, $127.7\left(\mathrm{C}-2^{\prime}, \mathrm{C}-6^{\prime}\right), 128.4\left(\mathrm{C}-3^{\prime}, \mathrm{C}-5^{\prime}\right), 129.3(\mathrm{C}-7), 135.3,136.7,142.6$
(C-1', C-4a, C-8a), 163.3, 164.4 (CO-COO, CO-COO); HRMS (ESI) m/z calcd for $\mathrm{C}_{20} \mathrm{H}_{23} \mathrm{~N}_{2} \mathrm{O}_{5}[\mathrm{M}+\mathrm{H}]^{+} 371.1607$, found 371.1594; HPLC: $100 \%, \mathrm{t}_{\mathrm{r}} 11.3 \mathrm{~min}$; Anal. $\left(\mathrm{C}_{20} \mathrm{H}_{22} \mathrm{~N}_{2} \mathrm{O}_{5}\right): \mathrm{C}, \mathrm{H}, \mathrm{N}$.

4.1.17. 2-((3,5-Difluorobenzyl)(2-(hydroxymethyl)-2,4-dimethyl-3,4dihydro-2H-benzo[b][1,4]oxazin-7-yl)amino)-2-oxoacetic acid (17b)

Compound 17b was prepared by hydrolysis of ester $\mathbf{1 6 b}$ (434 mg, $1 \mathrm{mmol}$ ) with $1 \mathrm{M} \mathrm{LiOH}(6 \mathrm{~mL})$ in a mixture of tetrahydrofuran and methanol according to the procedure for the synthesis of compound 11a to obtain $292 \mathrm{mg}$ (72\%) of 17b as brown oil; ${ }^{1} \mathrm{H}$ NMR (400 MHz, DMSO- $\left.d_{6}\right) \delta$ ppm 1.19 (s, 3H, 2- $\mathrm{CH}_{3}$ ), 2.83 $\left(\mathrm{s}, 3 \mathrm{H}, \mathrm{NCH}_{3}\right), 2.90(\mathrm{~d}, J=11.7 \mathrm{~Hz}, 1 \mathrm{H}, 3-\mathrm{H}), 3.12(\mathrm{~d}, J=11.7 \mathrm{~Hz}, 1 \mathrm{H}$, 3-H), 3.31 (d, $J=10.8 \mathrm{~Hz}, 1 \mathrm{H}, \mathrm{CH}_{2} \mathrm{O}$ ), 3.41 (d, $J=10.8 \mathrm{~Hz}, 1 \mathrm{H}, \mathrm{CH}_{2} \mathrm{O}$ ), $4.86\left(\mathrm{~s}, 2 \mathrm{H}, \mathrm{CH}_{2} \mathrm{~N}\right), 5.05$ (bs, $\left.1 \mathrm{H}, \mathrm{OH}\right), 6.53-6.66\left(\mathrm{~m}, 3 \mathrm{H}, \mathrm{Ar}-\mathrm{H}^{8}, \mathrm{Ar}-\right.$ $\left.\mathrm{H}^{6}, \mathrm{Ar}-\mathrm{H}^{5}\right), 6.92\left(\mathrm{~d}, J=6.6 \mathrm{~Hz}, 2 \mathrm{H}, \mathrm{Ar}-\mathrm{H}^{2^{\prime}}, \mathrm{Ar}-\mathrm{H}^{6^{\prime}}\right), 7.04-7.18$ $\left(\mathrm{m}, 1 \mathrm{H}, \mathrm{Ar}-\mathrm{H}^{4^{\prime}}\right) ;{ }^{13} \mathrm{C}$ NMR (101 MHz, DMSO- $\left.d_{6}\right) \delta \mathrm{ppm} 20.8$ $\left(2-\mathrm{CH}_{3}\right), 38.1\left(\mathrm{NCH}_{3}\right), 50.1\left(\mathrm{CH}_{2} \mathrm{~N}\right), 53.2(\mathrm{C}-3), 65.0\left(\mathrm{CH}_{2} \mathrm{O}\right), 76.0$ $(\mathrm{C}-2), 102.9\left(\mathrm{t},{ }^{2} J_{\mathrm{C}-\mathrm{F}}=25.8 \mathrm{~Hz}, \mathrm{C}-4^{\prime}\right), 110.7\left(\mathrm{dd},{ }^{2} J_{\mathrm{C}-\mathrm{F}}=18.6 \mathrm{~Hz},{ }^{4} J_{\mathrm{C}-}\right.$ $\left.\mathrm{F}=6.8 \mathrm{~Hz}, \mathrm{C}-2^{\prime}, \mathrm{C}^{\prime} \mathrm{6}^{\prime}\right), 111.5$ (C-5), 114.1 (C-8), 119.7 (C-6), 129.0 (C-7), 135.4 (C-8a), $141.4\left(t,{ }^{3} J_{C-F}=8.9 \mathrm{~Hz}, \mathrm{C}-1^{\prime}\right), 142.6$ (C-4a), 162.4 (dd, $\left.{ }^{1} J_{C-F}=246.5 \mathrm{~Hz},{ }^{3} J_{\mathrm{C}-\mathrm{F}}=13.2 \mathrm{~Hz}, \mathrm{C}-3^{\prime}, \mathrm{C}^{\prime} 5^{\prime}\right), 163.4(\mathrm{CO}-\mathrm{COO}), 164,2$ (CO-COO); HRMS (ESI) $\mathrm{m} / \mathrm{z}$ calcd for $\mathrm{C}_{20} \mathrm{H}_{21} \mathrm{~N}_{2} \overline{\mathrm{O}_{5} \mathrm{~F}_{2}}[\mathrm{M}+\mathrm{H}]^{+}$ 407.1419, found 407.1414; HPLC: 93.0\%, $\mathrm{t}_{\mathrm{r}} 12.4 \mathrm{~min}$; Anal. $\left(\mathrm{C}_{20} \mathrm{H}_{20} \mathrm{~N}_{2} \mathrm{O}_{5} \mathrm{~F}_{2}\right): \mathrm{C}, \mathrm{H}, \mathrm{N}$.

\subsubsection{Cell cultures}

Bovine aortic endothelial cells (BAEC) were kindly provided by Prof. M. Presta (Brescia, Italy). Human cervical carcinoma (HELA) and human breast carcinoma (MCF-7) cells were obtained from the American Type Culture Collection (ATCC, Middlesex, UK). The cells were grown in Dulbecco's modified minimum essential medium (DMEM, Life Technologies, Inc., Rockville, MD) supplemented with $10 \mathrm{mM}$ Hepes (Life Technologies, Inc., Rockville, MD) and 10\% fetal bovine serum (FBS, Harlan Sera-Lab Ltd., Loughborough, UK). Human microvascular endothelial cells (HMEC-1) were obtained from the Centers of Disease Control (CDC, Atlanta, GA) and grown in EGM-2 medium with supplements and growth factors (Lonza, Verviers, Belgium).

\subsubsection{Cell proliferation assays}

Cells (HMEC-1, BAEC, HELA or MCF-7) were seeded in 48-well plates at 10,000 cells per $\mathrm{cm}^{2}$. After $16 \mathrm{~h}$, the cells were incubated in fresh medium in the presence of the test compounds, as indicated in the Results section. On day 4, (BAEC, HELA, MCF-7) or day 7 (HMEC-1) cells were trypsinized and counted by means of a Coulter counter (Analis, Belgium). For each compound, the $\mathrm{IC}_{50}$ value was determined. This is the concentration of compound that causes $50 \%$ inhibition of cell proliferation.

\subsubsection{Cell migration assay}

Wounds were created in confluent MAEC monolayers with a 1.0$\mathrm{mm}$ wide micropipette tip. Then, cells were incubated in fresh medium in the presence of the test compounds. After $5 \mathrm{~h}$, the wounds were photographed and the width of the wound was calculated from digital pictures. For statistical analyses, the $p$ values were determined using the Student $t$ test, and $p$ values $<0.05$ were considered significant.

\subsubsection{Tube formation assay}

Wells of a 96-well plate were coated with $60 \mu \mathrm{l}$ matrigel $(10 \mathrm{mg} /$ $\mathrm{mL}$, BD Biosciences, Heidelberg, Germany) at $4{ }^{\circ} \mathrm{C}$. After gelatinization at $37^{\circ} \mathrm{C}$ during $30 \mathrm{~min}$, HMEC- 1 (60,000 cells) were seeded on top of the matrigel in $200 \mu \mathrm{l}$ DMEM containing the test compounds. After $4-6 \mathrm{~h}$ of incubation, the cells were photographed and tube formation was quantified by giving a score from 0 (no 
tubes) to 3 (maximal tube formation, comparable to non-treated control cultures). Statistical analysis was performed by using the Student $t$ test, and $p$ values $<0.05$ were considered significant.

\subsubsection{CAM assay}

Fertilized eggs were incubated for 3 days at $37^{\circ} \mathrm{C}$ when $3 \mathrm{~mL}$ of albumen was removed (to detach the shell from the developing CAM) and a window was opened on the eggshell exposing the CAM. The window was covered with cellophane tape and the eggs were returned to the incubator until day 9 when the compounds were applied. The compounds were placed on sterile plastic discs ( $\varnothing$ $8 \mathrm{~mm}$ ), which were allowed to dry under sterile conditions. A solution of cortisone acetate $(100 \mathrm{lg} /$ disc, Sigma, St. Louis, MO) was added to all discs in order to prevent an inflammatory response. A loaded and dried control disc was placed on the CAM approximately $1 \mathrm{~cm}$ away from the disc containing the test compound(s). Next, the windows were covered and the eggs further incubated until day 11 when the area around the discs was cut-off and photographed. Next 2 concentric circles were positioned on the digitalized pictures and all vessels intersecting these circles were counted. Statistical analysis was performed by using the Student $t$ test, and $p$ values $<0.05$ were considered significant.

\subsubsection{In vitro VEGFR2 kinase assay}

A radiometric protein kinase assay $\left({ }^{33}\right.$ PanQinase ${ }^{\circledR}$ Activity Assay) was used for measuring the kinase activity of the VEGFR2 protein kinase. VEGFR2 tyrosine kinase was expressed in Sf9 insect cells as human recombinant GST-fusion protein. The kinase was purified by affinity chromatography using GSH-agarose. The purity of the kinase was checked by SDS-PAGE/silver staining and the identity of the kinase was verified by mass spectroscopy. The $\mathrm{IC}_{50}$ profile of two compounds $1 \mathrm{a4}$ and $1 \mathrm{1a5}$ (both in racemic form as trifluoroacetate salts) was determined. IC 50 values were measured by testing 10 concentrations $\left(1 \times 10^{-4} \mathrm{M}\right.$ to $\left.3 \times 10^{-9} \mathrm{M}\right)$ of each compound. The measurements have been performed by ProQinase company in singlicate [32].

\section{Acknowledgments}

This work was supported by Slovenian Research Agency Grant No. P1-208, Slovene Hungarian bilateral project BI-HU/09-10-006, COST Action CM0602 - Inhibitors of Angiogenesis: design, synthesis and biological exploitation, and the Flemish grant FWO (G. 0486.08). Financial support by project VEGA 2/0112/10 is gratefully acknowledged. Miloš Ilić thanks Ad Futura Fundation for scholarship. The authors wish to thank Mrs. Eef Meyen for dedicated technical help. Péter Mátyus and Petra Dunkel are grateful for a support provided by the National Development Agency, Hungary (TÁMOP-4.2.1/B-09/1/KMR-2010-0001).

\section{References}

[1] M. Prins, H.-M.M. Otten, Thrombosis and cancer: a short history of Trousseau's syndrome, in: A. Falanga, A. Kakkar, F. Rickles (Eds.), Thrombosis and Cancer, Taylor and Francis, London, 2004, pp. 1-10.

[2] H.T. Sorensen, L. Mellemkjaer, F.H. Steffensen, J.H. Olsen, G.L. Nielsen, The risk of diagnosis of cancer after primary deep venous thrombosis or pulmonary embolism, N. Engl. J. Med. 338 (1998) 1169-1173.

[3] M.L.R. Nierodzik, F. Kajumo, S. Karpatkin, Effect of thrombin treatment of tumor cells on adhesion of tumor cells to platelets in vitro and tumor metastasis in vivo, Cancer Res. 52 (1992) 3267-3272.

[4] N.E. Tsopanoglou, M.E. Maragoudakis, On the mechanism of thrombininduced angiogenesis, J. Biol. Chem. 274 (1999) 23969-23976.
[5] M.L. Nierodzik, S. Karpatkin, Thrombin induces tumor growth, metastasis, and angiogenesis: evidence for a thrombin-regulated dormant tumor phenotype, Cancer Cell 10 (2006) 355-362.

[6] N.E. Tsopanoglou, M.E. Maragoudakis, On the mechanism of thrombininduced angiogenesis: inhibition of attachment of endothelial cells on basement membrane components, Angiogenesis 1 (1997) 192-200.

[7] M. Caunt, Y. Huang, P. Brooks, S. Karpatkin, Thrombin induces neoangiogenesis in the chick chorioallantoic membrane, J. Thromb. Haemost. 1 (2003) 2097-2102.

[8] S. Sabrkhany, A.W. Griffioen, M.G.A. oude Egbrink, The role of blood platelets in tumor angiogenesis, Biochim. Biophys. Acta 1815 (2011) 189-196.

[9] J. Folkman, Angiogenesis: an organizing principle for drug discovery, Nat. Rev. Drug Discov. 6 (2007) 273-286.

[10] P. Carmeliet, Angiogenesis in health and disease, Nat. Med. 9 (2003) 653-660.

[11] N. Ferrara, R. Kerbel, Angiogenesis as a therapeutic target, Nature 438 (2005) 967-974.

[12] M. Cristofanilli, C. Charnsangavej, G.N. Hortobagyi, Angiogenesis modulation in cancer research: novel clinical approaches, Nat. Rev. Drug Discov. 1 (2002) 415-426.

[13] J. Rhee, P.M. Hoff, Angiogenesis inhibitors in the treatment of cancer, Expert Opin. Pharmacother. 6 (2005) 1701-1711.

[14] R.S. Samant, Recent advances in anti-angiogenic therapy of cancer, Oncotarget 2 (2011) 122-134.

[15] C.A. Staton, Current status and future prospects for anti-angiogenic therapies in cancer, Expert Opin. Drug Discov. 4 (2009) 961-979.

[16] S. Pennacchietti, P. Michieli, M. Galluzzo, M. Mazzone, S. Giordano, P.M. Comoglio, Hypoxia promotes invasive growth by transcriptional activation of the met protooncogene, Cancer Cell 3 (2003) 347-361.

[17] P.S. Steeg, Angiogenesis inhibitors: motivators of metastasis, Nat. Med. 9 (2003) $822-823$.

[18] J.M.L. Ebos, C.R. Lee, W. Cruz-Munoz, G.A. Bjarnason, J.G. Christensen, R.S. Kerbel1, Accelerated metastasis after short-term treatment with a potent inhibitor of tumor angiogenesis, Cancer Cell 15 (2009) 232-239.

[19] M. Pàez-Ribes, E. Allen, J. Hudock, T. Takeda, H. Okuyama, F. Viñals, M. Inoue, G. Bergers, D. Hanahan, O. Casanovas, Antiangiogenic therapy elicits malignant progression of tumors to increased local invasion and distant metastasis Cancer Cell 15 (2009) 220-231.

[20] J. Sleeman, P.S. Steeg, Cancer metastasis as a therapeutic target, Eur. J. Cancer 46 (2010) 1122-1180.

[21] P. Štefanič Anderluh, M. Anderluh, J. Ilaš, J. Mravljak, M. Sollner Dolenc, M. Stegnar, D. Kikelj, Toward a novel class of antithrombotic compounds with dual function. Discovery of 1,4-benzoxazin-3(4H)-one derivatives possessing thrombin inhibitory and fibrinogen receptor antagonistic activities, J. Med. Chem. 48 (2005) 3110-3113.

[22] J. Ilaš, Ž. Jakopin, T. Borštnar, M. Stegnar, D. Kikelj, 3,4-Dihydro-2H-1,4benzoxazine derivatives combining thrombin inhibitory and glycoprotein IIb/IIIa receptor antagonistic activity as a novel class of antithrombotic compounds with dual function, J. Med. Chem. 51 (2008) 5617-5629.

[23] (a) M. Ilić, D. Kikelj, J. Ilaš, Fluorinated dual antithrombotic compounds based on 1,4-benzoxazine scaffold, Eur. J. Med. Chem. 50 (2012) 255-263; (b) M. Ilić, P. Dunkel, J. Ilaš, E. Chabielska, A. Zakrzeska, P. Mátyus, D. Kikelj, Enantiomers of potential dual antithrombotic compounds based on 2,3dihydro-1,4-benzodioxine scaffold, Submitted for publication.

[24] L.M. Khachigian, C.R. Parish, Phosphomannopentaose sulfate (PI-88): heparan sulfate mimetic with clinical potential in multiple vascular pathologies, Cardiovasc. Drug Rev. 22 (2004) 1-6.

[25] V. Ferro, K. Dredge, L. Liu, E. Hammond, I. Bytheway, C. Li, K. Johnstone, T. Karoli, K. Davis, E. Copeman, A. Gautam, PI-88 and novel heparan sulfate mimetics inhibit angiogenesis, Semin. Thromb. Hemost. 33 (2007) 557-568.

[26] M. Ilić, J. Ilaš, S. Liekens, P. Mátyus, D. Kikelj, Synthesis and antiproliferative activity of 2-(([1,2,4]triazolo[4,3-b]- pyridazin-6-yloxy)methyl)-2,4-dimethyl3,4-dihydro-2H-benzo[b][1,4]oxazine derivatives, ARKIVOC (2011) 298-311.

[27] M. G. Kelly, J. Kincaid, S. Janagani, M. Duncton, U.S. Pat. Appl. 20060205773, 2006 Chem.Abstr. (2006) 145336048.

[28] R. Auerbach, R. Lewis, B. Shinners, L. Kubai, N. Akhtar, Angiogenesis assays: a critical overview, Clin. Chem. 49 (2003) 32-40.

[29] S. Liekens, A.I. Hernández, D. Ribatti, E. De Clercq, M.J. Camarrasa, M.J. PérezPérez, J. Balzarini, The nucleoside derivative 5-O-trityl-inosine (KIN59) suppresses thymidine phosphorylase-triggered angiogenesis via a noncompetitive mechanism of action, J. Biol. Chem. 279 (2004) 29598-29605.

[30] A.D. Crawford, S. Liekens, A.R. Kamuhabwa, S. Munck, A. Breyne, J. Maes, R. Busson, J. Rozenski, C.V. Esguerra, P.A.M. de Witte, Zebrafisch bioassayguided natural product discovery: isolation of angiogenesis inhibitors from East African medical plants, Plos One 6 (2011) e14694.

[31] I. Arnaoutova, J. George, H.K. Kleinman, G. Benton, The endothelial cell tube formation assay on basement membrane turns 20: state of the science and the art, Angiogenesis 12 (2009) 267-274.

[32] Determination of Inhibition IC50 Activity on VEGFR2 Receptor has been Performed by ProQinase GmbH, Freiburg, Germany http://www.proqinase.com/. 